\title{
State Fragility and Resilience in sub-Saharan Africa
}

This book focuses on the indicators of fragility and the resilience of state-led interventions to address them in sub-Saharan Africa. It analyzes the 'figure' of fragile states as the unit of analysis and situates the study of fragility, governance and political adaptation within contemporary global and local political, economic and socio-cultural contexts.

The chapters offer an indispensable, econometrically informed guide to better understanding issues that have an impact on fragility in governance and nationbuilding and affect policy-making and program design targeting institutions in various circumstances. These issues, as they relate to the indicators of fragility, are the contexts and correlates of armed conflicts on statehood and state fragility, the poverty-trap, pandemics and household food insecurity, and child labor. Case studies from across 46 sub-Saharan African (SSA) countries are assessed to offer clear, broad and multidisciplinary views of what the future holds for them and the international donor communities at large. Regarding state-led interventions, the authors utilize insightful statistical methods and epistemologies to explain the correlates of behavioral language frames and conflict de-escalation on battlerelated deaths across the conflict zones within the sub-region, the regional and country-level interventions to end child labor, the institutional frameworks and interventions in the advancement of food security and health.

This book will be of interest to scholars of economics, development, politics in developing countries, Area and African Studies, peace, conflict and security studies.

John Idriss Lahai is a Research Fellow at the University of New England, Australia.

Isaac Koomson is a $\mathrm{PhD}$ candidate at the UNE Business School at the University of New England, Australia. 


\section{Routledge Contemporary Africa Series}

The International Criminal Court and the Lord's Resistance Army Enduring Dilemmas of Transitional Justice

Joseph Otieno Wasonga

African Intellectuals in the Post-colonial World

Fetson A. Kalua

National Healing, Integration and Reconciliation in Zimbabwe

Ezra Chitando, Kelvin Chikonzo and Nehemiah Chivandikwa

Africa's Elite Football

Structure, Politics, and Everyday Challenges

Chuka Onwumechili

Social Licensing and Mining in South Africa

Sethulego Matebesi

The Everyday Life of the Poor in Cameroon

The Role of Social Networks in Meeting Needs

Nathanael Ojong

Introduction to Rwandan Law

Jean-Marie Kamatali

State Fragility and Resilience in sub-Saharan Africa

Indicators and Interventions

John Idriss Lahai and Isaac Koomson

For more information about this series, please visit: www.routledge.com/ Routledge-Contemporary-Africa/book-series/RCAFR 


\section{State Fragility and Resilience in sub-Saharan Africa}

Indicators and Interventions

John Idriss Lahai and Isaac Koomson

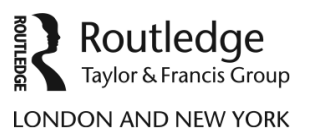


First published 2020

by Routledge

2 Park Square, Milton Park, Abingdon, Oxon OX14 4RN

and by Routledge

52 Vanderbilt Avenue, New York, NY 10017

Routledge is an imprint of the Taylor \& Francis Group, an informa business

(C) 2020 John Idriss Lahai and Isaac Koomson

The right of John Idriss Lahai and Isaac Koomson to be identified as authors of this work has been asserted by them in accordance with sections 77 and 78 of the Copyright, Designs and Patents Act 1988.

All rights reserved. No part of this book may be reprinted or reproduced or utilized in any form or by any electronic, mechanical, or other means, now known or hereafter invented, including photocopying and recording, or in any information storage or retrieval system, without permission in writing from the publishers.

Trademark notice: Product or corporate names may be trademarks or registered trademarks, and are used only for identification and explanation without intent to infringe.

British Library Cataloguing-in-Publication Data

A catalogue record for this book is available from the British Library

Library of Congress Cataloging-in-Publication Data

Names: Lahai, John Idriss, author. | Koomson, Isaac, author.

Title: State fragility and resilience in sub-Saharan Africa : indicators and interventions / John Idriss Lahai and Isaac Koomson.

Description: Abingdon, Oxon ; New York, NY : Routledge, 2020. | Series: Routledge contemporary Africa | Includes bibliographical references and index. | Identifiers: LCCN 2019044841 | ISBN 9780367410797 (hardback) | ISBN 9780367853846 (ebook)

Subjects: LCSH: Political stability-Africa, Sub-Saharan. |

Nation-building-Africa, Sub-Saharan. | Conflict management-Africa, Sub-Saharan. | Child labor-Africa, Sub-Saharan. | Food security-Africa, Sub-Saharan. | Africa, Sub-Saharan-Social conditions-21st century.

Classification: LCC JQ1875 .L35 2020 | DDC 320.967-dc23

LC record available at https://lccn.loc.gov/2019044841

ISBN: 978-0-367-41079-7 (hbk)

ISBN: 978-0-367-85384-6 (ebk)

Typeset in Times New Roman

by Wearset Ltd, Boldon, Tyne and Wear 


\section{Contents}

List of figures vii

List of tables viii

1 Introduction 1

PART I

Statehood and conflicts: contextual indicators and interventions

2 Conceptualizing the state, state fragility and resilience in the political economy of sub-Saharan Africa

3 Frames of impact: the contexts and correlates of armed conflicts on state fragility

4 Behavioral language frames, conflict de-escalation, and battle-related deaths: a panel estimation of peace accords across zones of conflict

PART II

Child labor: thematic indicators and interventions

5 Child labor, poverty and fragility

6 Regional and country-level interventions to end child labor 
vi Contents

\section{PART III}

Food (in)security: contextual indicators and interventions

7 The Ebola pandemic and household food insecurity

8 Institutional interventions in the advancement of food security and health

9 Conclusion

Index 


\section{Figures}

4.1 Conflict frames - inputs, outputs and expected outcomes 71

4.2 Scatter plot of battle-related deaths (best measure) and reconciliatory words

4.3 Scatter plot of battle-related deaths (low measure) and reconciliatory words

4.4 Scatter plot of battle-related deaths (high measure) and reconciliatory words

5.1 The link between fragility and child labor in fragile states, multiple countries

5.2 Child labor across the regions of the world

5.3 Child labor by gender in Africa (SSA, ESA, WCA, MENA)

5.4 What will happen if you stop working?

7.1 Food insecurity across three rounds of the survey 


\section{Tables}

3.1 Theoretical standpoints and methodologies that have been deployed to explain the causes of conflict

4.1 Abbreviations for CDW - conflict de-escalation word

4.2 Methods of imaginations, comprehension, storage and transmission of conflict escalation and de-escalation words in situations of conflicts in sub-Saharan Africa

4.3 Definitions and sources of variables

4.4 Summary statistics and presentation of countries

4.5 Pooled OLS regression for the effect of conflict de-escalation words on battle-related deaths

5.1 OLS estimation for the effect of poverty on number of child labor hours within a household

5.2 OLS estimation for the effect of household income on number of child labor hours within a household

6.1 Anti-child labor policies and institutional/operational/legal frameworks of case study countries

6.2 The framing of child interventions through 12 themes in the five national policies

$\begin{array}{lll}7.1 & \text { Consumption by product (2011) } & 162\end{array}$

$\begin{array}{ll}7.2 & \text { General indicators (2011-2014) } \\ & 163\end{array}$

7.3 Land area cultivated between 2008 and 2011

7.4 Food self-sufficiency (import vs export and net trade as $\%$ of GDP)

7.5 Descriptive statistics of variables used in estimating the socioeconomic determinants of household food insecurity

7.6 Eigen values from principal component analysis (unrotated $=$ principal)

7.7 Principal components (eigenvectors) rotated loadings

7.8 Random effects model for socio-economic determinants of household food insecurity

7.9 Poisson random effects model for socio-economic determinants of household intensity of food insecurity 
Tables ix

8.1 Overview of regional-level resilient food security policies to combat food insecurity and malnutrition shock and stress

8.2 Overview of country-level resilient food security and nutrition policies to combat food insecurity and malnutrition shock and stress

8.3 NAFCO's start-up operational stock and emergency government stocks 


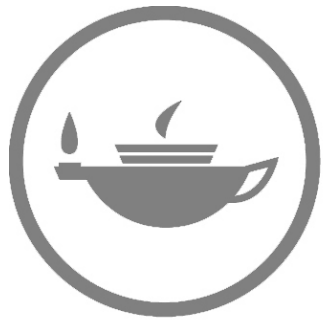

Taylor \& Francis Taylor \& Francis Group http://taylorandfrancis.com 


\section{Introduction}

National harmonies, the needs of an internationalized economy, group interests, classes and legal structures did not prevent conflict coming, did not ameliorate it when it did come, did not fight it and did not win it. It was governments [used interchangeably with the state] that fought it and did win it, by intricate calculations as to strategy and tactics, by mobilizing the political, material and psychological resources of nations, through appeal to the national interest (Hans J. Morgenthau, in Politics Among Nations (published in 1948) quoted in Navari 1991, 4). In this book we argue that the postcolonial state in subSaharan Africa cannot be trivialized, given its role in the making of the indicators of fragility: such as conflict, political instability, poverty, pandemics, corruption, food insecurity, gender inequality and child labor. Despite - or because of - this role, however, the postcolonial state should be seen as a resilient actor; one with a central role in managing economic, social and political fragility. Building on empirical discussions and statistical models of fragility and the role of the state, we propose two theoretical frameworks to understand, first (in Part I of this book), the critical indicators of fragility; and, second (in Part II), using the 'fragility-as-resilience' discourse as an 'affective analytical tool,' the character of state resilience and interventions, with particular emphasis on the state-centric approaches.

Why a state-centric approach? We believe this framework enables us to describe, predict and understand the meaning of the 'state,' and to challenge the existing knowledge about it within the limits of relevant epistemological and practical assumptions. Having said that, we recognize - and, in fact, problematize - the existential crisis the concept of 'state' (including its place and power) is currently undergoing. We also note that the increase in political interventions in the region is not driven solely by altruistic motives. The routinization of governmental interventions to end fragility is also driven by a power-seeking desire not just to control the resilience spaces at all levels of the state, but also to transform them into platforms for experimentation either with externally framed neoliberal peace and development policies or with indigenous policies that would guarantee these governments' political survival - at all costs, and by whatever means possible.

In view of the historical pre-eminence of such self-serving intervention, some would argue against the use of a state-centric approach. The question thus arises: 


\section{Introduction}

why is the re-centering of the state relevant to our study of fragility and state resilience in the region? On the one hand, we believe a state-centric approach challenges, to use the words of Marta Iniguez de Heredia and Zubairu Wai, "the dominant and hegemonic notion that Africa is peripheral, exceptionally outside world politics [and the international political economy, or IPE], and marginal." This aim provides legitimacy to approaches (including that proposed here) that "constitute an elegant epistemological critique of [the IPE] and how it relates to Africa, painting a complex picture of the dynamics of [the global economy], the larger structures within which is produced, and Africa's place in it" (de Heredia and Wai 2018, jacket). On the other hand, the centering of the state is also about explaining the functions that only the state can perform. It was Hans J. Morgenthau (in Politics Among Nations, published in 1948) who reminded us that

national harmonies, the needs of an internationalized economy, group interests, classes and legal structures did not prevent conflict coming, did not ameliorate it when it did come, did not fight it and did not win it. It was governments [used interchangeably with the state] which fought it and did win it, by intricate calculations as to strategy and tactics, by mobilizing the political, material and psychological resources of nations, through appeal to the national interest.

(Quoted in Navari 1991, 4)

Morgenthau was seeking to draw our attention to that which we should not lose sight of, namely, the relevance and resilience of the state. His call, though he was speaking on behalf of Western countries at a time when they were struggling for world domination against another contender, the Soviet Union, has relevance today and can be applied in the context of state fragility. The turn of events following the end of the Cold War in 1989 had unwanted consequences for sub-Saharan Africa. There was an upsurge in civil conflicts (as reactions against the regimes created by and for the Cold War powers) and other indicators of fragility. But, with the world becoming a global village, the turmoil of the region can no longer be characterized as 'problems of Africa,' for its people and governments to deal with alone.

In the place of indifference, what can best be described as an interdisciplinary social science and humanistic inquiry into Africa's state/hood, fragility crises and societal resilience has emerged. Political scientists have turned their attention to what constitutes 'political behavior' in situations of fragility. These 'fragile' situations are "[p]eriods when states or institutions lack the capacity, accountability, or legitimacy to mediate relations between citizen groups and between citizens and the state, making them vulnerable to violence" (World Bank 2011a, xvi, 2011b). 'Fragile situations' have either (a) a harmonized average Country Policy and Institutional Assessment (CPIA) rating of 3.2 or less, or (b) the presence of a $\mathrm{UN}$ and/or regional peace-keeping or peace-building mission within the past three years (World Bank 2003, cited in Ferreira 2015, 34). Sociologists of the functionalist school understand that sub-Saharan African countries are becoming 
increasingly complex and differentiated due to globalization (see Shizha and Diallo 2016). Globalization has brought socialized forms of political mobilities (Urry 2000), civilizational ideas of justice and power (Sriram 2004, 2005) and other forms of network activities (Pieterse 1994) into societies hitherto resistant to the influences of Western modernity (Gill 2003; Taylor and Nel 2002; Gelb and Floyd 1999). As such, there is growing sociological inquiry into the forces shaping people's lived experiences, and the consequences of such experiences, within the structures and functions of these dysfunctional societies. Gender studies scholars also have something to say: that structural gender inequality should be considered in the explanations of the causes and consequences of fragility (Caprioli 2005; Kevane 2004). Ethnologists and anthropologists, who were among the first to embrace the idea of societal resilience in the fragile spaces of sub-Saharan Africa (see Moore 1994; Nyamnjoh 2012; Herskovits 1959), have also begun to look at the biological and physiological aspects of societies in the making and unmaking of fragility (Comaroff and Comaroff 1993; Bryceson 2006). Empiricist peace studies scholars (Bertocchi and Guerzoni 2012; Boege et al. 2008, 2009; Renders and Terlinden 2010) and journalists (Somerville 2016) have also embraced the idea that not all histories of fragility fall into the category of fragility; some forms of fragility may equally be understood as episodic events shaping the evolving hybrid political orders.

Meanwhile, economists studying the rise and fall of market forces in the IPE have begun to draw correlations between relative deprivation, greed and grievances, and conflicts (Collier and Hoeffler 2004; Collier and Sambanis 2005; Collier, Hoeffler and Rohner 2009), the arms-industrial complex (Tan 2014; Dunne and Tian 2013) and the volatility of markets in the capitalist North and political instability in Africa (Berdal and Malone 2000; Moore 2000). They have realized that there would be an adverse impact on consumption patterns in Paris, New York, London, Sydney and Toronto, among other major consumer economies, were there to be an international rights-based outcry against child labor in the cocoa bean plantations of, say, the Ivory Coast (Amanor 2012; Squicciarini and Swinnen 2016); they have realized that the outbreak of, say, Ebola, in any sub-Saharan African country would impact the global tourism industries and, hence, the livelihood of millions employed by this sector in Western Europe, the Asia-Pacific and North America (Lahai 2017). With patterns of consumer behaviors and the trends of demand and supply in the developed economies inextricably tied, to an extent, to what happens in the volatile spaces of subSaharan Africa, IPE has expanded to accommodate a sub-discipline of 'the political economy of development in Africa.'

Of course, one should not forget the role played by scholars of postcolonial theory. They challenged the peripherality of Africa in the IPE and its marginal status in the development of policies that would affect the governments and peoples of the postcolonial African states (de Heredia and Wai 2018; Wai 2014). For them, the inclusion of Africa as a region in the theoretical evolution of the IPE discipline is Orwellian; a discipline that has historically encouraged theories situating Africa as a space on the margins of the broader international system, 


\section{Introduction}

even when this space owes its fragility to European economic inventions, to imperialism and liberalism, with little room for alternative paths. While 'Africans' are recognized, the hegemonic nature of liberalism has clearly rendered the African state subservient to the power of the hegemon; a hegemon that seeks to invalidate the global relevance of Africa in order to sustain its geopolitical power. Thus, despite a recognition that would supposedly take Africa 'out of the global shadows' in a neoliberal world order' (Ferguson 2006), the invalidation of the relevance of the African states - so the postcolonialist theorists tell usmakes it all but impossible to end fragility. And where this marginality persists, the people of these spaces will continue to wear, stoically and with a sense of inferiority, the stereotypes and stigma associated with their being and knowing. Made to think that they are responsible for their backwardness, both their efforts to bring back Africa into mainstream international relations and IPE scholarship and their ability to help their states out of the fragility trap are predicated on a reading in which they are dependent on externally formulated policies. These theorists have re-created narratives in which the 'who' that created the conditions for fragility mitigation was, at some point in the histories of Sub-Saharan Africa, also responsible for the militarized desertification of 'what' would have enabled their successor-states to break free of neo-colonial conditioning of their development and governance. Against this backdrop, they question the assumption that the fragile sub-Saharan states had a 'comparative advantage' that should have enabled them to develop on the basis of agricultural and natural resource products exported to the west. For them, sub-Saharan Africa cannot benefit from any such advantage as long as Africa remains on the margins of the international political and economic landscape. If anything, sub-Saharan Africa's marginality, which was not of its own making, has reinforced economic and political fragility in the region.

That said, how the fundamentals of fragility and the roles of the state, both in the making of fragility and in building resilient communities, are understood also depends on discourses of 'place' and 'power.' The spatial theorists Robert W. Preucel and Lynn Meskell $(2004,215)$ define 'place' as the "outcome of the social process of valuing space; a product of the imaginary, of desire, and the primary means by which we articulate with space and transform it into a humanized landscape." Place, they tell us, is about space - "the physical setting in which everything occurs" (ibid.). While recognizing the postmodern argument that space is a 'relative' term, for the purposes of this book we understand it as a passive 'container' that encapsulates the (1) physical enclosures of territoriality, and (2) “civil inclusionary exclusivity" (Halfmann 1998, quoted in Mau 2012, 8) —which basically means, "how the nation-state is still able to control the inclusion - and by extension, the exclusion — of people in various functional systems." Thus, "regardless of their close connections to the geographical space known as the nation-state, diverse groups of people can be treated differently" according to whether they are viewed as legitimate members of the space (Ndhlovu 2018, 5); and, as an addendum, those who reside outside their legitimate spaces can be viewed as outsiders by the people of that place, based on what they make of such sojourners' 
place of origin. Thus, for example, an African living in the United States of America can be viewed and subjected to increased security surveillance if the U.S. government and people see his region and country of origin as a space that represents an existential threat to their national security. To this end, the study of space has undergone considerable advances (or, rather, taken a 'spatial turn') since it was first theorized in 1974 by the French Marxist philosopher and sociologist Henri Lefebvre in La production de l'espace (see Gottdiener 1993; Lefebvre 1991; Goonewardena et al. 2008). This 'spatial turn' constitutes our understanding (for the purpose of this book) of place as a platform that is not static but, instead, a projected space where the struggles over ideas, beliefs, principles and bodies take place.

In the circumstances, then, it is not surprising that the tensions and contradictions of place, have led some to go as far as to hold that what constitutes place has a correlation to power - the operational definition of which, Robert Alan Dahl tells us, is the "successful attempt by A to get B to do something he would not otherwise do" (Dahl 1957, 202). In Dahl's view, the polyarchic descriptor, 'appropriateness' (i.e., the political actions of governments), and the impact of power, as it relates to legitimate governance policies, procedures, and actions of the state, should be assessed with regard to governmental performance in preventing and managing the indicators of fragility in sub-Saharan Africa. If we are to examine the indicators of fragility and political resilience based on government performance, then the need to re-center the African state becomes all the more critical. A noteworthy observation, however, is that our attempt to bring the African state 'back' into the center is not premised on the belief that it is a unitary actor. In a globalizing world with many centers of powers and actors, the state is a component of the whole. Adding to this observation, we also accept that, notwithstanding the presence of existential threats to its survival, the state is the actor that provides the space for all other things to occur and acts as the regulator, whether directly or indirectly, of the activities of those within its political space (territory).

In relation to the second framework, 'fragility-as-resilience,' we employ (and expand on) Nicolas Lemay-Hébert's (2018) working definition of the term, and his differentiation of the 'old' approaches to fragility (that see fragility as a place of no return) from the 'new' empirical positioning of the word 'fragility' (as it relates to state-building and as 'risk-mitigation') with resilience-building as the fundamental premise of its normative possibilities (Lemay-Hébert 2018). For Lemay-Hébert, the problem with 'fragility' is not solely its dangers, but the validity of the knowledge that is resistant to the shift from the old to the new. He believes - and we agree - that

general retreat in the [epistemic] community from the labelling of fragile states towards a more complex understanding of 'states of fragility' is a way of recognising the growing resistance to the concept - thus the retreat - but in doing so, this move also opens up new governmentality opportunities for policy actors, re-engaging on the familiar field of securitisation. 


\section{Introduction}

This shift or rather, 'retreat,' he contends, exposes the ways in which one can look at the operational aspects of the words 'resilience' and 'fragility.' These words, according to Lemay-Hébert, operate through the dualist conception of securitization: "securitization of the other" (i.e., pathologizing specific states and societies while legitimizing international intervention) and "securitization of the self," or moving towards new risk mitigation strategies. This is what we rely on for our empirical analyses of the issues covered in Part II of this book, on state resilience and intervention. These issues (with each discussed in individual chapters) are: (1) Behavioral language frames, conflict de-escalation words and the reduction of battle-related deaths; (2) Regional and country-level interventions to end child labor; and (3) Institutional interventions in the advancement of food security and health. However, a point of departure from Lemay-Hébert's conceptualization - which should be seen as our contribution to this emerging, expanding concept - is our attention to the state. It is our belief that, despite the characterization of the 'state' as fragile and, therefore, a problem to be excised, its resilience in the face of the odds against it should not be dismissed. To do so would only reinforce the problem of indifference to the state of fragility in subSaharan Africa.

\section{The significance of the book}

This book focuses on core issues of relevance to the political economy of subSaharan African countries. These issues, as they relate to the indicators of fragility, are the 'contexts and correlates of armed conflicts on statehood and state fragility'; the poverty trap; pandemics and household food insecurity; and child labor and poverty. Regarding the interventions, we developed insightful empirical methods and theories to explain the correlate of behavioral language frames and conflict de-escalation on battle-related deaths across the zones of conflicts; regional and country-level interventions to end child labor; institutional frameworks and interventions in the advancement of food security and health. Taken together, these are issues that have thus far received limited systematic, multidisciplinary and empirically informed critical analysis that may help to understand fragility and resilience better.

Against this backdrop, this book makes a major contribution to the literature in the following ways. First, since the 1980s scholars of the applied social sciences and humanities have discussed a range of state fragility and failure trends in sub-Saharan Africa. The current literature on these trends mostly falls within single sub-disciplines, such as econometrics or political science or anthropology, it is also characterized by inconclusive normative assumptions that were either not tested across countries in sub-Saharan Africa, or were not designed to confront the new realities of state resilience in this sub-region, or by sweeping generalizations from non-empirically tested studies built on a small number of practical cases. In the course of researching this book, we conducted a literature review of over 270 scholarly works (journal articles, chapter contributions in edited volumes and books) on statehood, fragility and resilience in sub-Saharan 
Africa, and found only a small number (around 50) based on original empirical data that covers the whole region. Further, none of these 270 scholarly works employed methodological frameworks (within a single study) that drew from mathematical and applied linguistics, securitization theory, political theory, legal theory (and international labor law), applied child development theories and applied econometric techniques in the analyses of statehood, fragility and resilience in the political economy of sub-Saharan Africa. The research in this book employs all these methodologies and theories - as well as contributing a new theory, which we call the "theory of conflict de-escalating words (CDWs)"- in examining, in Part II, the critical indicators of fragility and, in Part III, the institutional frameworks and interventions to reverse the incidences of fragility in sub-Saharan African.

Second, as of the time of writing this book, there are few critical works that comparatively analyze the impact of the contexts and correlates of internal and internationalized armed conflicts on state fragility. The few authoritative works on these are located mostly in the global North and build on the ground-breaking work of Paul Collier and Anke Hoeffler on vertical inequality (2004), Frances Stewart on horizontal inequality (2006), the World Bank on institutional trust (2011a) and Mary Caprioli on gender structural inequalities (2000, 2005). Even where these works form the core of the empirical leanings of the literature, our literature review reveals that they are limited to the shorter pieces of book reviews published in the supplementary sections of refereed journals. What we do, in Chapter 3 of this book, is use the theoretical directions and tools and indices of these ground-breaking works to understand how the context-specific 'lived experiences' of peoples are imagined, understood and theorized, on the one hand; and, on the other, how definitional variations in their representations of conflicts-including those presented by the Uppsala Conflict Data Program ${ }^{1}$ (1997-2013) - enable us to understand the convergences and divergences in theorization and the causal effects of armed conflicts and the indicators of state fragility (as listed by the Fund for Peace (2017)) on the measurement of the adaptive resilience of states. It is this observation that makes this book, to the best of our knowledge, one of the first (if not the first) to systematically engage these works and indices to explain the context-specific representations of conflict-induced state fragility. As of the time of writing this book, there is no literature that looks at the impact of conflict de-escalating words (in peace accords signed between 1989 and 2002 across 13 sub-Saharan African) in the reduction of battle-related deaths. At the time of writing this book, and to the best of our knowledge, there is no study that employs frame analysis to comparatively scrutinize the national anti-child-labor policies of countries across the five subregional economic blocs of sub-Saharan Africa, with the aim of understanding the impact of legal norms (international and regional labor law, international human rights law) and institutional regimes in eliminating the worst forms of child labor. The existing studies that have attempted to cover the other issues presented in our book are neither pluri-disciplinary nor empirically extensive. Thus, this book is an important scholarly contribution that not only studies the 


\section{Introduction}

indicators of state fragility but also suggests the relevance of having 'child labor' as a stand-alone indicator of state fragility. As of today, the category 'child' is missing in the indexes of state fragility in sub-Saharan Africa; and, in tandem, what we suggest, with regards to our theory of conflict de-escalation words, has just opened up the field of securitization theory (of the Copenhagen school).

Finally, we recognize the existence of several outstanding books, journal articles, book chapters and policy papers that have broadened our understanding of the indicators of, and interventions to resolve, state fragility in sub-Saharan Africa. There are also many scholarly works that have treated the problem of fragility and pathways of resolving the drivers of state fragility through narrow theoretical frames, which, in turn, makes their methodologies problematic. Our book unifies these thematic topics into one volume and employs insightful methodological approaches to understand these issues. Thus, institutions and people with an interest state fragility need look no further for a work that contains all the indicators of, and interventions against, state fragility in sub-Saharan Africa. This book makes a significant contribution to multiple sub-fields of state fragility studies. We say "multiple sub-fields" because our book will be of interest to various disciplines: Area and African studies, political science, development studies, micro/macroeconomics, gender and women's studies, peace, security and conflict studies, childhood studies, critical postcolonial studies, sociology, anthropology, applied linguistics, quantitative research methods and international relations. As such, it contains everything that would be relevant to policy-makers and academic institutions. We cannot assume that this is the only book that will tell the story of state resilience in sub-Saharan Africa. As we shall see below, there are other texts that address one or more of the thematic issues we cover. In fact, the eras of the Millennium Development Goals (MDGs) (2002-2016) and the SDGs (2016 to date) have contributed to a rapid shift of attention to the role of governments in sub-Saharan Africa-from a unit (of analysis) posing a danger to global peace and security in a mostly neoliberal world order (and hence, a problem to be excised and contained (Amin 2006)), to a partner in the global-local ( $\mathrm{glo}-\mathrm{cal}$ ) pursuits of sustainable political stability, and social and economic development (Sachs 2012; Nilsson et al. 2016; World Health Organization 2015).

\section{Summary of the chapters}

In this book, readers are provided with some insights into how we got involved in the project and some anecdotes on the data collection. We introduce the reader to the topics of the book, and the central questions it addresses. It discusses the significance of the book; and, finally, discusses the outline of the book.

The first chapter gives the reader an understanding that the fundamental issues underlying the problem of state fragility in sub-Saharan Africa are not as straightforward as they may appear. This is, in part, due to the way the roles of African governments are understood and theorized. Some authors have gone so far as to 
hold that the triggers of fragility in the region are mere reoccurrences of what life has always been in its habitable spaces; and, hence, of little cause for global concern. Others, while recognizing the global dimensions to the woes of this crisis-ridden region, have, nonetheless, pointed to the contestations surrounding the 'state': what it is, and what has been its role in the making/unmaking of fragility. They have questioned whether the African state should be regarded as a proactive agent in the building of resilient communities that can cope with the impact of fragility. They would like to know more about the ways in which the 'state,' whose leadership is responsible for creating some of the structures that foster fragility, can also be the driver for the unmaking of the fragile spaces in the region. To others, the issues go beyond the wrongs of the state. It should also be about its resilience in the face of the odds. That said, this introductory chapter argues that the postcolonial state in Africa cannot be dismissed because of its role in the making of some of the fragility indicators: conflicts, political instability, poverty, pandemics, corruption, household food insecurity, gender inequality and [child labor]. It should also be seen as a resilient actor, with a central role in the case management of the incidences of economic, social and political fragility. Building on empirical discussions and statistical models of fragility and the role of the state, we propose two theoretical frameworks to understand, in Part I of this book, the critical indicators of fragility, and, in Part II, the character of state resilience and interventions, with emphasis on the state-centric approach and the 'fragility-as-resilience' discourse.

In the second chapter, we observe that despite the existence of many theories of conflict escalation and de-escalation; and the methods and datasets that are guiding the multi-dimensional framing of the correlation between conflicts and fragility, the lack of consensus on what causes conflicts has had far-reaching consequences. Attempts to synchronize the context-specific agendas of professionals in the field (individuals, agencies and governments) into these multi-layered academic positions (be they dominant or peripheral), and their definitions of the various forms of conflicts, have had an impact on the measurement of indicators of conflicts. We recognize that, despite the existence of definitions, datasets and databases, the literature on the intersection between conflict and state fragility in SSA is not conclusive. Against this backdrop, our intention in the first half of this chapter is to present (a) the tools and adaptive indices that have been used to measure the causes and causal effect of conflicts, (b) summaries of the definitions and typologies of conflicts, and (c) the key theoretical perspectives (and their methodological frameworks) on the causes of conflict in sub-Saharan Africa. In the second half, we scrutinize the ways in which the proponents of those perspectives have imagined, understood and theorized the context-specific variations of the impact of conflict on state fragility. In addition, our aim is to contribute to the existing studies on conflict by focusing on attempts to centralize the experiences of states - that is, as actors representing the collective emotions (and knowledge) of the people within them. Through this, we are able to reveal the convergences and divergences in the theoretical (and practical) underpinnings of conflict as a critical indicator of state fragility and a tool for measuring the resilience of states in SSA. 
The third chapter deals with the contexts and correlates of conflict. We problematize the various perspectives that have been presented to understand the political economy of war and peace; greed and grievance; and needs and wants, and their correlation to the making and unmaking of wars in Africa. The fourth chapter begins with the questions: Would the mainstreaming of conflict deescalation words (CDWs) in the outcome documents - Peace Accords (PAs) - of state-led political settlements of conflicts lead to a reduction of battle-related deaths in a year or two following the conclusions of peace negotiations? We infer that the more CDWs are found in PAs the lesser the incidences of battle-related deaths; and the higher the number of words of stalemate (such as sanctions and criminal prosecution of faction leaders) the higher the incidences of battlerelated deaths. Our findings show that the effect of reconciliatory words on battlerelated deaths depicts an inverted-U relationship. This therefore called for a rigorous statistically verified threshold analysis to discover the number of words that can trigger this relationship. We focus on 49 Peace Accords (with emphasis on 145 key semantic and syntactical observations) across countries in sub-Saharan Africa (from 1990 to 2003) to count not just the number of times conflict deescalation words were used, but also to de-construct their meanings and connections to state-led efforts to resolve conflicts and reduce battle-related deaths. Our empirical threshold analysis pegs the number of conflict de-escalating words at 35. What this means is that, increasing the amount of reconciliatory words in a peace accord beyond 35 can reduce the number of battle-related deaths. To count these reconciliatory words in these peace accords, we used Nvivo to run a text search and validated the outcome with a manual Hand Tally Counter. We also deconstruct frame meanings and their connections to state-led efforts to reduce battle-related deaths. In the first section, we explore the literature on the relevance of (non-)linearity of the semantic and syntactic aspects of language framing in the study of conflict escalation/de-escalation. Linguistically speaking, they are two different frames; but in the discourse of securitization, they are opposed to each other. Whereas CDWs have effects that depict a peaceful end: the reversal of existential threats in political speech acts on incidences that deserve special securitized executive action. In the second section, we introduce our theory of CDWs. We situate this theory in Walter J. Ong's theorization of literate and oracy countries, with recognition of the Afrocentric readings of peace in the decolonized platforms of alternative dispute resolution at the sub-regional levels. In the third section, using scatter plots, pooled OLS and random effect models, we show why and how these words or frames of conflict de-escalation contribute to a reduction in battle-related deaths. Our findings reveal that the lesser the amount of reconciliatory words included in a peace accord, the higher the number of battle-related deaths - per any additional non-reconciliatory word; but the number of deaths begins to decline with the mainstreaming of higher amounts of reconciliatory words. In this context, we suggest the choice to project CDWs is to get parties in a conflict to think less about warfare and more about ways of getting out of what the Hirshleifer-Skaperdas game theory of conflict has referred to as adversarial traps, with the rent-seeking soundbites for resource (for war) appropriation. 
The fifth chapter paints a realistic image of the African child laborer-the omitted category in the measurement indicators of state fragility. We observe that there is a decreasing rate in the incidence of child labor in major regions of the world but the situation in sub-Saharan Africa is experiencing an upward trend despite governments' improved efforts with the objective of curbing the menace within the sub-region. This chapter extends the existing child laborpoverty nexus to state fragility by drawing on theoretical and empirical evidence using survey data from two countries: Ghana and Tanzania. Our synthesis of empirical findings with the extant literature shows that poor and low-income parents subject their children to relatively more hours of child labor, thereby putting their economic and social prospects in jeopardy. We also find that some of the children engaged in worst forms of child labor are entrapped in commercial sex exploitation, are forcibly recruited into non-state armed groups while others deal in illicit drugs. The negative implication of this outcome is that child labor activities perpetually impoverish the children, their immediate societies and their countries due to the vicious cycle of poverty or largely owing to economic failures on the part of the state. Victims of these economic and political failures who begin to feel disenfranchised become the source of uprisings and upheavals, leaving the country(s) branded as a fragile state. Accordingly, studies have found that poverty is one key driver of child labor, along with a poorly developed agricultural sector, high population growth/fertility rates and low levels of educational attainment and participation. This chapter draws the linkages between poverty, child labor and state fragility by drawing on theoretical and empirical evidence from Ghana, and Tanzania. SSA is the focus given that it has the highest incidence of child labor in the world; the International Labour Organization (ILO) has also indicated that a breakthrough in Africa would be critical to ending child labor worldwide. The relevance of the child labor discourse is reflected in the pledges by governments in SSA to take pragmatic steps in achieving the United Nations Sustainable Development Goals (SDGs). The rest of this chapter proceeds as follows. Section two deals with child labor activities in SSA and is followed by a section on definitions of child labor. Section four discusses the child labor-poverty nexus, while section five provides a discussion on the cycle of poverty in fragile states. Section six examines the prospects of child labor and its implications for society while section seven outlines the methodology used in the data analyses. Here, we talk about the theories, the data source, the cross-sectional data and Logit estimation technique employed in the data analyses. The analysis is done for the estimations because they both seek to provide empirical evidence for the effect of household wealth on child labor outcomes. Post-estimation tests such as the link test is used to ensure that the models are correctly specified while the variance inflation factor (VIF) is also employed to avoid the usage of models that suffer from multicollinearity.

The sixth chapter traces, in part one, the political and legal histories of the antichild labor regimes in sub-Saharan Africa. This is to demonstrate that the discourse on the need for a robust national plan or policy to combat the worst forms of child labor is supported by regional institutional and legal advancements, which 


\section{Introduction}

fall within a broader, multidimensional international human rights regime. It is this argument that provides the basis for the second section, which addresses the politics of re-affirmation of the global child protection regime brought by the African Charter on the Rights and Welfare of the Child (ACRWC). We examine, using frame theory, the country-level advances in the elimination of the worst forms of child labor. We scrutinize the national plans of five sub-Saharan African countries-selected from an extensive poll of countries within the five subregional economic blocs in the region: Cameroon (from the Economic Community of Central African States (ECCAS) sub-region); Kenya (the Intergovernmental Authority for Development, IGAD); Ghana (the Economic Community of West African States, ECOWAS); Tanzania (the East African Community, EAC); and Zimbabwe (the Southern African Development Community, SADC). We examine how the construct of 'intervention' (which seeks to fulfil the fundamental aspects of international human rights law and the emergent doctrine of an international responsibility to protect: prevent, react and rebuild) is structured through 15 subframes of the themes of (1) social programming, (2) legal proactivity and (3) institutional interventions, monitoring and evaluation. We look at the similarities in the framing of risk management as it relates to medical, social, nutrition, criminal prosecution and compulsory schooling interventions. Whereas frame theory was the umbrella scheme we used to understand subject matter similarities, for the legal proactivity section, we employed French and Raven's (1959) “The Basis of Social Power Theory," to ascertain the impact of the national laws on child labor on the society. On the issue of institutional intervention, we also draw from the various behavioral and child development theories of Sigmund Freud, Erik Erikson, Jean Piaget, John Bowlby and Lev Vygotsky.

In the seventh chapter, we contend that since the onset of the Ebola Virus Diseases (EVD) in Guinea in 2013, the estimated number of resultant deaths for all three affected countries was more than 11,000 out of 27,000 reported cases by June 2015. Of all the affected countries, Sierra Leone reported the highest number of cases of 12,901 with 3,915 deaths. The nature of the pandemic and the resultant deaths have socioeconomic and food insecurity implications for affected households. The chapter examines socio-economic determinants of food insecurity at the household level in Sierra Leone using six indicators of food insecurity. Data for the chapter are the three rounds of the High Frequency Cell Phone Survey data that were jointly collected by Statistics Sierra Leone (SSL) and Innovations for Poverty Action (IPA). Empirical techniques include Random-effects Poisson and population-averaged Poisson models. We generate an index of food insecurity from six household coping strategies that indicate food insecurity, using principal component analysis, and employ the household unitary model since the data used for the analyses was generated by focusing on the household head. Findings indicate that households that engage in agriculture only are more have a higher risk of being food insecure. On the contrary, households that have diversified their income portfolios experience a reduction in their levels of food insecurity as incomes from their non-farm enterprises experience boost. We also find that households in 
Freetown are less food insecure compared to their counterparts in other urban areas. In specific terms, we find that incomes from non-farm enterprises significantly reduce the intensity at which households restrict adult consumption for small children to eat. Similar reductions in food insecurity intensities can be said for households that rely on less preferred or expensive food as well as those that reduce number of meals eaten in a day. This is the grounds on which we stand to recommend that households in fragile states engage in income diversification to mitigate the harsh conditions of food insecurity in times of an Ebola pandemic.

The eighth chapter sets out to show that, while the increasing incidences of food insecurity impose enormous pressure on what governments can do at the national levels to mitigate against health shocks, it has not prevented them from developing innovative policies to increase crop yield and increase their per capita dietary energy supply (DES) in line with FAO's aggregated estimates of household energy (kcal) consumption per day. The primary objectives of this chapter are, first, to evaluate the goals, policy directives and guiding principles of the national food and nutrition policies of sub-Saharan African countries that received a country ranking and overall score in the 2017 Global Food Security Index. Second, the identified goals are our baseline in exploring some of the key strategies and interventions to contain food insecurity. That said, we begin this chapter with an overview of the causes of food insecurity. In the second section, we examine the various strategies states have used to end food insecurity; using the Ghana model on buffer food stock as a guide, we examine the magnitude of the transfers between the agricultural sector and the health sector. The aim here is to determine whether this model (attending especially to its best practices and lessons) can be replicated in countries that were affected by the Ebola Virus Disease of 2014 and 2016. We seek to ascertain how this Ghana model can be used to transform the food and nutrition security regimes of these countries. Finally, the concluding chapter discusses the role of research in the contemporary theorization of state interventions to address the incidence of state fragility in subSaharan Africa.

\section{Note}

$1 \mathrm{https}: / /$ ucdp.uu.se/

\section{References}

Amanor, Kojo Sebastian. 2012. "Global Resource Grabs, Agribusiness Concentration and the Smallholder: Two West African Case Studies." The Journal of Peasant Studies 39 (3-4): 731-749.

Amin, Samir. 2006. "The Millennium Development Goals: A Critique from the South." Monthly Review 57 (10): 1.

Berdal, Mats R. and David Malone. 2000. Greed \& Grievance: Economic Agendas in Civil Wars. Boulder, CO: Lynne Rienner Publishers. 


\section{Introduction}

Bertocchi, Graziella, and Andrea Guerzoni. 2012. "Growth, History, or Institutions: What Explains State Fragility in Sub-Saharan Africa?" Journal of Peace Research 49 (6): 769-783.

Boege, Volker, Anne Brown, Kevin Clements, and Anna Nolan. 2008. On Hybrid Political Orders and Emerging States: State Formation in the Context of 'Fragility. 'Berlin, Germany: Berghof Center for Constructive Conflict Management. http://berghofhandbook.net/documents/publications/boege_etal_handbook.pdf.

Boege, Volker, M. Anne Brown, and Kevin P. Clements. 2009. "Hybrid Political Orders, Not Fragile States." Peace Review 21 (1): 13-21.

Bryceson, Deborah Fahy. 2006. "Fragile Cities: Fundamentals of Urban Life in East and Southern Africa." In African Urban Economies: Viability, Vitality or Vitiation?, edited by Deborah Fahy Bryceson and Deborah Potts, 3-38. New York, NY: Palgrave Macmillan.

Caprioli, Mary. 2000. “Gendered Conflict.” Journal of Peace Research 37 (1): 51-68.

Caprioli, Mary. 2005. "Primed for Violence: The Role of Gender Inequality in Predicting Internal Conflict." International Studies Quarterly 49 (2): 161-178.

Collier, Paul, and Anke Hoeffler. 2004. "Greed and Grievance in Civil War." Oxford Economic Papers 56 (4): 563-595.

Collier, Paul, Anke Hoeffler, and Dominic Rohner. 2009. "Beyond Greed and Grievance: Feasibility and Civil War." Oxford Economic Papers 61 (1): 1-27.

Collier, Paul, and Nicholas Sambanis. 2005. Understanding Civil War: Africa. Vol. 1. Washington, DC: World Bank Publications.

Comaroff, Jean, and John L. Comaroff, eds. 1993. Modernity and Its Malcontents: Ritual and Power in Postcolonial Africa. Chicago, IL: University of Chicago Press.

Dahl, Robert A. 1957. "The Concept of Power." Systems Research and Behavioral Science 2 (3): 201-215.

Dunne, J. Paul, and Nan Tian. 2013. "Military Expenditure and Economic Growth: A Survey." The Economics of Peace and Security Journal 8 (1): 5-11.

Ferguson, James. 2006. Global Shadows: Africa in the Neoliberal World Order. Durham, NC: Duke University Press.

Ferreira, Ines Afonso Roque. 2015. "Defining and Measuring State Fragility: A New Proposal.” In, 39. Berkeley, CA. http://cega.berkeley.edu/assets/miscellaneous_files/109_ABCA_2015_Ines_Ferreira_Defining_and_measuring_state_fragility_A_new_proposal_ May15.pdf.

Gelb, Alan, and Rob Floyd. 1999. "The Challenge of Globalisation for Africa." South African Journal of International Affairs 6 (2): 1-17.

Gill, Stephen. 2003. "Globalisation, Market Civilisation and Disciplinary Neoliberalism." In Globalization: Critical Concepts in Sociology, edited by Roland Robertson and Kathleen White, 256-81. London, UK: Routledge.

Goonewardena, Kanishka, Stefan Kipfer, Richard Milgrom, and Christian Schmid, eds. 2008. Space, Difference, Everyday Life: Reading Henri Lefebvre. New York, NY: Routledge.

Gottdiener, Mark. 1993. "A Marx for Our Time: Henri Lefebvre and the Production of Space.” Sociological Theory 11 (1): 129-134.

Heredia, Marta Iñiguez de, and Zubairu Wai, eds. 2018. Recentering Africa in International Relations: Beyond Lack, Peripherality, and Failure. New York, NY: Palgrave Macmillan.

Herskovits, Melville J. 1959. "Anthropology and Africa-a Wider Perspective." Africa 29 (3): 225-238.

Kevane, Michael. 2004. Women and Development in Africa: How Gender Works. Boulder, CO: Lynne Rienner Publishers. 
Lahai, John Idriss. 2017. The Ebola Pandemic in Sierra Leone: Representations, Actors, Interventions and the Path to Recovery. Basingstoke, Hampshire: Palgrave Macmillan.

Lefebvre, Henri. 1991. The Production of Space (Translated by Donald NicholsonSmith). Oxford, UK: Blackwell Publishing.

Lemay-Hébert, Nicolas. 2018. "From Saving Failed States to Managing Risks: Reinterpreting Fragility through Resilience." In Governance and Political Adaptation in Fragile States, edited by John Idriss Lahai, Karin von Strokirch, Howard Brasted, and Helen Ware. New York, NY: Palgrave Macmillan.

Mau, Steffen. 2012. Social Transnationalism: Lifeworlds Beyond the Nation-State. New York, NY: Routledge.

Moore, David. 2000. 'Levelling the Playing Fields \& Embedding Illusions: 'Post-Conflict' Discourse \& Neo-Liberal 'Development' in War-Torn Africa." Review of African Political Economy 27 (83): 11-28.

Moore, Sally Falk. 1994. Anthropology and Africa: Changing Perspectives on a Changing Scene. Charlottesville, Virginia: University of Virginia Press.

Navari, Cornelia. 1991. "Introduction: The State as a Contested Concept in International Relations." In The Condition of States: A Study in International Political Theory, edited by Cornelia Navari, 1-18. Buckingham, UK: Open University Press.

Ndhlovu, Finex. 2018. Language, Vernacular Discourse and Nationalisms: Uncovering the Myths of Transnational Worlds. New York, NY: Palgrave Macmillan.

Nilsson, Maans, Dave Griggs, and Martin Visbeck. 2016. "Policy: Map the Interactions between Sustainable Development Goals.” Nature News 534 (7607): 320.

Nyamnjoh, Francis B. 2012. "Blinded by Sight: Divining the Future of Anthropology in Africa." Africa Spectrum, 63-92.

Pieterse, Jan Nederveen. 1994. "Globalisation as Hybridisation." International Sociology 9 (2): 161-184.

Preucel, Robert W., and Lynn Meskell. 2004. "Places.” In A Companion to Social Archaeology, edited by Lynn Meskell and Robert W. Preucel, 215-229. Malden, Massachusetts: Blackwell Publishing.

Renders, Marleen, and Ulf Terlinden. 2010. "Negotiating Statehood in a Hybrid Political Order: The Case of Somaliland." Development and Change 41 (4): 723-746.

Sachs, Jeffrey D. 2012. "From Millennium Development Goals to Sustainable Development Goals." The Lancet 379 (9832): 2206-2211.

Shizha, Edward, and Lamine Diallo. 2016. Africa in the Age of Globalisation: Perceptions, Misperceptions and Realities. Abingdon, UK: Routledge.

Somerville, Keith. 2016. Africa's Long Road since Independence: The Many Histories of a Continent. London, UK: Hurst Publishers.

Squicciarini, Mara P. and Johan Swinnen, eds. 2016. The Economics of Chocolate. Oxford, UK: Oxford University Press.

Sriram, Chandra Lekha. 2004. "Globalising Justice: From Universal Jurisdiction to Mixed Tribunals." Netherlands Quarterly of Human Rights 22 (1): 7-32.

Sriram, Chandra Lekha. 2005. Globalizing Justice for Mass Atrocities: A Revolution in Accountability. Abingdon, UK: Routledge.

Stewart, Frances. 2006. "The Implications of Horizontal Inequality for Aid." CRISE Working Paper, No. 36. Oxford: CRISE, University of Oxford.

Tan, Andrew T. H., ed. 2014. The Global Arms Trade: A Handbook. Abingdon, UK: Routledge. 


\section{Introduction}

Taylor, Ian, and Philip Nel. 2002. " 'New Africa', Globalisation and the Confines of Elite Reformism: 'Getting the Rhetoric Right', Getting the Strategy Wrong." Third World Quarterly 23 (1): 163-180.

Urry, John. 2000. Sociology beyond Societies: Mobilities for the Twenty-First Century. London, UK: Routledge.

Wai, Zubairu. 2014. "The Empire's New Clothes: Africa, Liberal Interventionism and Contemporary World Order." Review of African Political Economy 41 (142): 483-499.

World Bank. 2011a. "Operationalizing the 2011 World Development Report: Conflict, Security, and Development." (Development Committee's Joint Ministerial Committee of the Borad of Governors of the Bank and the Fund on the Transfer of Real Resources to Developing Countries; DC2011-0003 (April 4). Washington, DC: World Bank. http:// siteresources.worldbank.org/DEVCOMMINT/Documentation/22884392/DC20110003\%28E\%29WDR2011.pdf.

World Bank. 2011b. "World Development Report 2011: Conflict, Security and Development." Washington, DC: World Bank. http://documents.worldbank.org/curated/en/ 806531468161369474/pdf/622550PUB0WDR0000public00BOX361476B.pdf.

World Health Organization. 2015. "Health in 2015: From MDGs, Millennium Development Goals to SDGs, Sustainable Development Goals." Geneva: World Health Organization. http://apps.who.int/iris/bitstream/handle/10665/200009/9789241? sequence $=1$. 
situation, the people of the sending state (the philanthropists; the saviors) need to be reassured. While the desire should always be to resolve the crisis, there are other self-seeking factors that may lead to a situation wherein the savior becomes the devil. Then again, African leaders have, in some cases, called for the securitization of their own states when faced with complex political and medical emergencies. For example, following the outbreak of the Ebola pandemic in West Africa in 2014, the leaders of affected countries (Sierra Leone, Liberia and Guinea) framed their messages to the UN using 'dependency discourses' that were, according to John Idriss Lahai, designed to motivate the West to accept, as sacrosanct, its moral responsibility to produce a comprehensive response to the pandemic, and to help those countries mitigate the impact Ebola-related restrictions on trade and transportation were having on their respective economies (Lahai 2017).

Despite this negative impact, this turn from failed states to countries at risk is about recognizing the resilience of fragile states. Resilience matters because it is so perceptibly and fundamentally what survival is all about. There are various notions of resilience, and many platforms on which it is demonstrated. Thus, the resilience of a state may be the will and ability to endure in the face of threats to its sovereignty-territoriality, as the scholars of realism theory contend; or it may derive from the activism of civil society in compelling the state to do more to provide the basic needs of her peoples, and to promote and protect their fundamental human rights, as development experts and human rights advocates recommend. State resilience may ultimately rest in the processes of rebuilding the institutions of governance after every episode of fragility so as to prevent such episodes from happening again, as peacebuilding scholars and practitioners would have it; or it may reside in the willingness of the leaders of government to subject themselves to the political appraisals of their electorates - and, for those voted out of office, the willingness to accept the democratic verdict of their electorates, as the advocates of democracy advise. Then again, state resilience may circulate through political and cultural accommodation of the political and cultural 'others' for the sake of peace, as Kantian theorists (who propound the deontological perpetual/moral peace theory of Immanuel Kant) argue. State resilience may come from the acceptance of the fragile states in the international system. Here, the dominant states can transform the international system into a dais of equity to enable the fragile states to be recognized as equal (though emerging) sovereign states, as advocates of the democratic theory predict. Or state resilience may offer the state the means by which its people can eliminate all politically motivated and culturally regulated patriarchal institutions and narratives that prevent the attainment of gender equality in politics, economics and society, as liberal feminists have suggested.

\section{Note}

1 According to the joint World Bank and African Development Bank Migration and Remittances Household Surveys conducted for the Africa Migration Project, reported 


\section{Statehood and conflicts}

that, sub-Saharan countries grew from its 2015 figures of $\$ 33$ billion to $\$ 37.8$ billion in 2017 ; with a two-year prediction that by 2019 , it will increase to $\$ 39.6$ billion. www. worldbank.org/en/topic/migrationremittancesdiasporaissues/brief/migration-remittancesdata (accessed: June 14, 2018).

\section{References}

Anter, Andreas. 2014. Max Weber's Theory of the Modern State: Origins, Structure and Significance. Basingstoke, Hampshire: Palgrave Macmillan.

Baliamoune-Lutz, Mina, and Mark McGillivray. 2011. "State Fragility: Concept and Measurement." Fragile States: Causes, Costs, and Responses, 33-42.

Balzacq, Thierry. 2005. "The Three Faces of Securitization: Political Agency, Audience and Context." European Journal of International Relations 11 (2): 171-201.

Bates, Robert H. 2008. "The Logic of State Failure: Learning from Late-Century Africa." Conflict Management and Peace Science 25 (4): 297-314.

Bertocchi, Graziella, and Andrea Guerzoni. 2012. "Growth, History, or Institutions: What Explains State Fragility in Sub-Saharan Africa?" Journal of Peace Research 49 (6): 769-783.

Buzan, Barry, and Ole Waever. 1997. "Slippery? Contradictory? Sociologically Untenable? The Copenhagen School Replies." Review of International Studies 23 (2): 241-250.

Caprioli, Mary. 2005. "Primed for Violence: The Role of Gender Inequality in Predicting Internal Conflict.” International Studies Quarterly 49 (2): 161-178.

Carment, David, and Yiagadeesen Samy. 2012. "Assessing State Fragility: A Country Indicators for Foreign Policy Report." Carleton University [with Canadian International Development Agency]. www.operationspaix.net/DATA/DOCUMENT/7374 V $\sim$ Assessing_State_Fragility_A_Country_Indicators_for_Foreign_Policy_Report.pdf.

Chauvet, Lisa, and Paul Collier. 2008. "What Are the Preconditions for Turnarounds in Failing States?" Conflict Management and Peace Science 25 (4): 332-348.

Clapham, Christopher. 2000. "Failed States and Non-States in the Modern International Order." In Failed States III: Globalization and The Failed State, 1-15. Florence, Italy: Strategic Outreach Program of the U.S. Army War College and the Office of International Programs, Purdue University. www.comm.ucsb.edu/faculty/mstohl/failed_ states/2000/failedstates.php.

Cleary, A. S. 1990. "The Myth of Mau Mau in Its International Context." African Affairs 89 (355): 227-245.

Dahl, Robert A. 1957. "The Concept of Power." Systems Research and Behavioral Science 2 (3): 201-215.

Dowdall, Harold Chaloner. 1923. “Word State.” Law Quarterly Review 39: 98-112.

Dunleavy, Patrick, and Brendan O'Leary. 1987. Theories of the State: The Politics of Liberal Democracy. Basingstoke, Hampshire: Macmillan Education Ltd.

Easterly, William, Ross Levine, and David Roodman. 2004. "Aid, Policies, and Growth: Comment." American Economic Review 94 (3): 774-780.

Ferreira, Ines Afonso Roque. 2015. "Defining and Measuring State Fragility: A New Proposal.” In, 39. Berkeley, CA. http://cega.berkeley.edu/assets/miscellaneous_files/109_ABCA_2015_Ines_Ferreira_Defining_and_measuring_state_fragility_A_new_proposal_ May15.pdf.

Fletcher, David, and Mustafa Sarkar. 2013. "Psychological Resilience." European Psychologist 18: 12-23. https://doi.org/10.1027/1016-9040/a000124. 
G7+. 2013. "Note on the Fragility Spectrum." G7+. www.g7plus.org/sites/default/files/ resources/g7\%2B\%2BEnglish $\% 2 \mathrm{BFS} \% 2 \mathrm{BNote} \% 2 \mathrm{BDesign}$.pdf.

Giddens, Anthony. 1985. The Nation-State and Violence. Vol. 2. Berkeley, CA: University of California Press.

Grant, Thomas D. 1999. "Defining Statehood: The Montevideo Convention and Its Discontents." Columbia Journal of Transnational Law 37 (2): 403-457.

Hampel, Karl. 2015. "The Dark (Er) Side of 'State Failure': State Formation and SocioPolitical Variation." Third World Quarterly 36 (9): 1629-1648.

Heath, Elizabeth. 2010. "Berlin Conference of 1884-1885." In Encyclopedia of Africa, edited by Kwame Anthony Appiah and Gates, 2: 177-175. Oxford, UK: Oxford University Press. www.oxfordreference.com/view/10.1093/acref/9780195337709.001. 0001/acref-9780195337709-e-0467.

Helman, Gerald B., and Steven R. Ratner. 1992. "Saving Failed States." Foreign Policy, 89 (3): 3-20.

Huysmans, Jef. 2011. "What's in an Act? On Security Speech Acts and Little Security Nothings." Security Dialogue 42 (4-5): 371-383.

Klute, Georg, and Trutz von Trotha. 2004. "Roads to Peace: From Small War to Parasovereign Peace in the North of Mali." In Healing the Wounds: Essays on the Reconstruction of Societies after War, edited by Marie-Claire Foblets and Trutz von Trotha, 109-143. Portland, OR: Hart Publishing.

Krasner, Stephen D. 1999. Sovereignty, International Relations Theory, and International Law. Princeton, NJ: Princeton University Press.

Lahai, John Idriss. 2017. The Ebola Pandemic in Sierra Leone: Representations, Actors, Interventions and the Path to Recovery. Basingstoke, Hampshire: Palgrave Macmillan.

Lahai, John Idriss, and Nenneh Lahai. 2018. "The History and Representations of the Challenges of Governance in the Fragile States of Sub-Saharan Africa." In Governance and Political Adaptation in Fragile States, edited by John Idriss Lahai, Karin von Strokirch, Howard Brasted, and Helen Ware, 1: 35-50. Basingstoke, Hampshire: Palgrave Macmillan.

Lemay-Hébert, Nicolas. 2018. "From Saving Failed States to Managing Risks: Reinterpreting Fragility through Resilience." In Governance and Political Adaptation in Fragile States, edited by John Idriss Lahai, Karin von Strokirch, Howard Brasted, and Helen Ware. New York, NY: Palgrave Macmillan.

Levitov, Alex. 2016. Normative Legitimacy and the State. Oxford, UK: Oxford University Press. www.oxfordhandbooks.com/view/10.1093/oxfordhb/9780199935307.001.0001/ oxfordhb-9780199935307-e-131.

Little, Kenneth. 1966. "The Political Function of the Poro. (Part II.)." Africa: Journal of the International African Institute 36 (1): 62-72.

MacGibbon, Iain C. 1957. "Customary International Law and Acquiescence." British Year Book of International Law 33: 115.

Mamdani, Mahmood. 1996. Citizen and Subject: Contemporary Africa and the Legacy of Late Colonialism. Princeton, NJ: Princeton University Press.

Mamdani, Mahmood. 2012. Define and Rule: Native as Political Identity. Cambridge, MA: Harvard University Press.

McDonald, Matt. 2008. "Securitization and the Construction of Security." European Journal of International Relations 14 (4): 563-587.

Naudé, Wim, Amelia U. Santos-Paulino, and Mark McGillivray, eds. 2011. Fragile States: Causes, Costs, and Responses. Oxford, UK: Oxford University Press. 


\section{Statehood and conflicts}

Osaghae, Eghosa E. 2006. "Colonialism and Civil Society in Africa: The Perspective of Ekeh's Two Publics." Voluntas: International Journal of Voluntary and Nonprofit Organizations 17 (3): 233-245.

Otto, Dianne. 1996. "Subalternity and International Law: The Problems of Global Community and the Incommensurability of Difference." Social \& Legal Studies 5 (3): 337-364.

Rabel, Ernst. 1941. "The Revision of the Treaties of Montevideo on the Law of Conflicts." Michigan Law Review 39 (4): 517-525.

Rasmussen, Thomas. 1974. "The Popular Basis of Anti-Colonial Protest." In Politics in Zambia, edited by William Tordoff, 40-61. Manchester, UK: Manchester University Press.

Redner, Harry. 1990. "Beyond Marx-Weber: A Diversified and International Approach to the State." Political Studies 38 (4): 638-653.

Richmond, Oliver P. 2009. "Becoming Liberal, Unbecoming Liberalism: Liberal-Local Hybridity via the Everyday as a Response to the Paradoxes of Liberal Peacebuilding." Journal of Intervention and Statebuilding 3 (3): 324-344.

Richmond, Oliver P. 2010. "Introduction." In Palgrave Advances in Peacebuilding: Critical Developments and Approaches, edited by Oliver P. Richmond, 1-13. New York, NY: Palgrave Macmillan.

Shaw, Malcolm N. 2017. International Law. 8th edition. New York, NY: Cambridge University Press.

Southwick, Steven M., George A. Bonanno, Ann S. Masten, Catherine Panter-Brick, and Rachel Yehuda. 2014. "Resilience Definitions, Theory, and Challenges: Interdisciplinary Perspectives.” European Journal of Psychotraumatology 5 (1): 25338.

Stritzel, Holger. 2007. "Towards a Theory of Securitization: Copenhagen and Beyond." European Journal of International Relations 13 (3): 357-383.

Wilde, Ralph. 2002. "The Skewed Responsibility Narrative of the Failed States Concept." ILSA Journal of International and Comparative Law 9 (2): 425-429.

Young, Tom. 1995. " “A Project to Be Realised”: Global Liberalism and Contemporary Africa.” Millennium 24 (3): 527-546. 
emerged in Nigeria (the Boko Haram insurgents; see Agbiboa 2013) and Somalia (Al-Shabaab; see Solomon 2014)). These terrorist factions have strong links to terrorist groups outside sub-Saharan Africa: in the Maghreb, the Middle East, and south-east and south-central Asia (see Agbiboa 2014a, 2014b, 2015). Conflicts can also be an outcome of the horizontal inequality and neglect of regions on the basis of race, such as the ongoing 'genocidal' conflict in Darfur, which began in 2003 (Lahai 2016b, 56).

Unfortunately, when assessing the implications of conflicts for state fragility in SSA, conclusions are often about trivializing (if not silencing) the resilience of the state. The dominant narrative of these discourses, in analyzing the problem of state incapacity, is the urgency of embracing a neoliberal path to peace, governance and democracy. It has been argued, however, that this path empowers, in the political sense, the very actors (warlords) whose military actions contribute to state fragility during conflicts, while also reinforcing the economic and political structures for fragility to persist in the aftermath of the conflict (see Pitcher et al. 2009; Englebert and Ron 2004; Willett 2005; Hansen 2006; Reno 1999; Lahai and Lyons 2016). As a corrective measure, we propose a contextual assessment of the impact of conflict on state fragility in SSA. As we have already noted, what we tabulate here are outcomes of our review of the relevant literature on the theories of conflict. With this in mind, we recognize that the complexities (relating to the symptoms, correlates and causes) of war may have cross-theoretical conclusions. Moreover, we do not attempt to scale impact based on which theory offers either the best (or worst) explanation.

\section{Notes}

1 Feminisms-without-borders, as we understand it (and as it relates to the study of feminist movements in SSA) denotes, what is intuitively 'pro-womanism' or what concerns the identity and plight of the 'Black African woman' in the fragile genderedspaces of the sub-continent, on the one hand; and, on the other, what is, theoretically speaking, pro-western feminism or the projection of the 'high theories' of the western feminists (for more on this, and the clashes between African and western feminists, see, for example, Lyons 2004, 3-8).

2 Department of Peace and Conflict Research, Data on Armed Conflict, www.prio.org/ Data/Armed-Conflict/ (accessed: June 27, 2018).

3 Ibid.

4 This database contains more than 170,000 systematic national (on U.S. soil) and international (elsewhere, outside the U.S.) terrorists attacks between 1970 and 2016 (with annual updates). SEE, www.start.umd.edu/gtd/ (accessed: June 18, 2018).

5 The RDWTI is a compilation of data from 1968 through 2009. See the following links (accessed: June 27, 2018): www.rand.org/nsrd/projects/terrorism-incidents. html; www.rand.org/topics/terrorism.html.

6 But, for all the obvious reasons, some feminist scholars have suggested that 'the penis' (the male organ) should be included as a weapon of war (see, Mullins 2009; Carter 2010). Thus, as the lived experiences of women in the civil wars of SSA reveals, rape crimes were systemically used to dislocate families and communities, and sometimes to effect population transfer in genocidal wars as was the case of 
Rwanda (see, Mullins 2009) and Darfur (see, Miller 2009); or to transfer sexually transmitted diseases to the women who would eventually infect their men (within their ethnic group of same) (see, Ruby Reid-Cunningham 2008). In some instances, rape of the women and girls was aimed at demoralizing the male members of the warring faction to whom these women victims belong (Clifford and Slavery 2008; Trenholm, Olsson, and Ahlberg 2011; Coulter 2009).

7 Project Ploughshares. n.d. Defining Armed Conflicts. http://ploughshares.ca/armedconflict/defining-armed-conflict/.

8 See, Department of Peace and Conflict Research. n.d. Definitions. www.pcr.uu.se/ research/ucdp/definitions/\#Extra-systemic_conflict.

9 Ibid., www.pcr.uu.se/research/ucdp/definitions/.

10 Project Ploughshares. n.d. Types of Armed Conflict. http://ploughshares.ca/armedconflict/types-of-armed-conflict/.

11 Ibid.

12 Ibid.; emphasis added.

13 An example of this was pre-1994 Rwanda, where the government of Juvénal Habyarimana had a state policy that called for the empowerment of only the Hutu ethnic group, and the marginalization of the Tutsi ethnic group (including any Hutu who was found to be sympathetic to the plight of the Tutsis) (Scott 2006). In response, the Tutsis formed a rebel group, the Front Patriotique Rwandais (FPR; or the Rwanda Patriotic Army, under their leaders, Fred Gisa Rwigyema (who was the leader of the FPR until his death October 1990 (Waugh 2004, 42-47)) and Paul Kagame and declared war on the Hutu-government in 1990 (Mamdani 2001).

14 However, there are other international factors responsible for the outbreak of this conflict. According to the BBC, in 1998, Rwanda accused the government of President Laurent Kabila of either supporting or not acting against the Hutu rebels who had fled into the Democratic Republic of Congo (DRC) after they were defeated by the Rwanda forces loyal to President Kagame. In response to Kabila's inaction, Rwanda declared war on the Hutu rebels inside Congo. With the Rwandan forces inside his country, Kabila sent his soldiers to support to the Hutu rebels. This conflict raged between 1988 and 2003. But the conflict between the Tutsis (loyal to President Kagame of Rwanda) and the Hutu rebels (who want the Tutsi exterminated continues in eastern DRC. See, www.bbc.com/news/world-africa-11108589.

\section{References}

Abrahamsen, Rita. 2000. Disciplining Democracy: Development Discourse and Good Governance in Africa. London, UK: Zed Books.

Agbiboa, Daniel. 2015. "Shifting the Battleground: The Transformation of Al-Shabab and the Growing Influence of Al-Qaeda in East Africa and the Horn." Politikon 42 (2): 177-194.

Agbiboa, Daniel E. 2014a. “Terrorism without Borders: Somalia's Al-Shabaab and the Global Jihad Network." Journal of Terrorism Research 5 (1): 27-34.

Agbiboa, Daniel E. 2014b. "Ties That Bind: The Evolution and Links of Al-Shabab." The Round Table 103 (6): 581-597.

Agbiboa, Daniel Egiegba. 2013. "Why Boko Haram Exists: The Relative Deprivation Perspective." African Conflict \& Peacebuilding Review 3 (1): 144-157.

Ajayi, S. Ibi. 2003. "Globalisation and Africa." Journal of African Economies 12 (suppl 1): $120-150$.

Alison, Miranda. 2004. "Women as Agents of Political Violence: Gendering Security." Security Dialogue 35 (4): 447-463. 
Amin, Samir. 1998. "Spectres of Capitalism." Monthly Review 50 (1): 36.

Amin, Samir. 2006. "Beyond Liberal Globalization: A Better or Worse World?" Monthly Review 58 (7): 30.

Arnson, Cynthia J. and I. William Zartman, eds. 2005. Rethinking the Economics of War: The Intersection of Need, Creed, and Greed. Washington, DC: Woodrow Wilson Center Press.

Ballentine, Karen. 2003. The Political Economy of Armed Conflict: Beyond Greed and Grievance. Boulder, CO: Lynne Rienner Publishers.

Bartusevičius, Henrikas. 2016. "Introducing the Categorically Disaggregated Conflict (CDC) Dataset." Conflict Management and Peace Science 33 (1): 89-110.

Bender, Gerald J. 1978. "Angola, the Cubans, and American Anxieties." Foreign Policy 31: 3-30.

Besley, Timothy, and Torsten Persson. 2008. "Wars and State Capacity." Journal of the European Economic Association 6 (2-3): 522-530.

Buzan, Barry. 2007. People, States \& Fear: An Agenda for International Security Studies in the Post-Cold War Era. Wivenhoe Park, UK: ECPR Press.

Caprioli, Mary. 2000. "Gendered Conflict.” Journal of Peace Research 37 (1): 51-68.

Caprioli, Mary. 2005. "Primed for Violence: The Role of Gender Inequality in Predicting Internal Conflict." International Studies Quarterly 49 (2): 161-178.

Caprioli, Mary, and Mark A. Boyer. 2001. "Gender, Violence, and International Crisis." Journal of Conflict Resolution 45 (4): 503-518.

Caprioli, Mary, and Peter F. Trumbore. 2003a. "Ethnic Discrimination and Interstate Violence: Testing the International Impact of Domestic Behavior." Journal of Peace Research 40 (1): 5-23.

Caprioli, Mary, and Peter F. Trumbore. 2003b. "Identifying Rogue States and Testing Their Interstate Conflict Behavior." European Journal of International Relations 9 (3): 377-406.

Carpenter, R. Charli. 2006. "Recognizing Gender-Based Violence against Civilian Men and Boys in Conflict Situations." Security Dialogue 37 (1): 83-103.

Carter, Kathleen R. 2010. "Should International Relations Consider Rape a Weapon of War?" Politics \& Gender 6 (3): 343-371.

Cederman, Lars-Erik, Halvard Buhaug, and Jan Ketil Rød. 2009. "Ethno-Nationalist Dyads and Civil War: A GIS-Based Analysis." Journal of Conflict Resolution 53 (4): 496-525.

Cederman, Lars-Erik, Kristian Skrede Gleditsch, and Halvard Buhaug. 2013. Grievances and Inequality in Civil Wars. New York, NY: Cambridge University Press.

Cederman, Lars-Erik, Nils B. Weidmann, and Kristian Skrede Gleditsch. 2011. "Horizontal Inequalities and Ethnonationalist Civil War: A Global Comparison." American Political Science Review 105 (3): 478-495.

Chwaszcza, Christine. 2013. "Hume and the Social Contract. A Systematic Evaluation." Rationality, Markets and Morals 4 (73): 108-130.

Clifford, Cassandra, and Stop Modern Slavery. 2008. "Rape as a Weapon of War and Its Long-Term Effects on Victims and Society." In 7th Global Conference Violence and the Contexts of Hostility. Budapest, Hungary. www.peacewomen.org/sites/default/files/ vaw_rapeasaweaponofwar_stopmodernslavery_may2008_0.pdf.

Collier, Paul, and Anke Hoeffler. 2004. "Greed and Grievance in Civil War." Oxford Economic Papers 56 (4): 563-595.

Collier, Paul, and Anke Hoeffler. 2005. "Resource Rents, Governance, and Conflict." Journal of Conflict Resolution 49 (4): 625-633. 
Collier, Paul, and Nicholas Sambanis. 2005. Understanding Civil War: Africa. Vol. 1. Washington, DC: World Bank Publications.

Coulter, Chris. 2009. Bush Wives and Girl Soldiers: Women's Lives through War and Peace in Sierra Leone. Ithaca, NY: Cornell University Press.

Dixon, Jeffrey S. 2014. What Causes Civil Conflicts? Back to "Grievance vs. Greed." Oxford, UK: Blackwell Publishing Ltd.

Dunn, John. 1995. The Political Thought of John Locke: An Historical Account of the Argument of the 'Two Treatises of Government'. 6th paperback reprint edition. Cambridge: Cambridge University Press.

Dyer, Silke J. 2007. "The Value of Children in African Countries - Insights from Studies on Infertility." Journal of Psychosomatic Obstetrics \& Gynecology 28 (2): 69-77.

Easterly, William. 2001. "Can Institutions Resolve Ethnic Conflict?” Economic Development and Cultural Change 49 (4): 687-706.

El Jack, Amani, Emma Bell, and Lata Narayanaswamy. 2003. Gender and Armed Conflict: Overview Report. Brighton, UK: BRIDGE, Institute of Development Studies, University of Sussex Brighton.

El-Bushra, Judy. 2000. "Transforming Conflict: Some Thoughts on a Gendered Understanding of Conflict Processes." In States of Conflict: Gender, Violence and Resistance, edited by Susie Jacobs, Ruth Jacobson, and Jennifer Marchbank, 66-86. London, UK: Zed Books.

Englebert, Pierre, and James Ron. 2004. "Primary Commodities and War: CongoBrazzaville's Ambivalent Resource Curse.” Comparative Politics 37 (1): 61-81.

Fatton, Robert. 1990. "Liberal Democracy in Africa." Political Science Quarterly 105 (3): 455-473.

Fox, Mary-Jane. 2004. "Girl Soldiers: Human Security and Gendered Insecurity." Security Dialogue 35 (4): 465-479.

Fund for Peace, The. 2017. "Fragile States Index: Indicators." Fragile States Index: Presented by The Fund for Peace. http://fundforpeace.org/fsi/indicators/.

Giles, Wenona, and Jennifer Hyndman, eds. 2004. Sites of Violence: Gender and Conflict Zones. Berkeley, CA: University of California Press.

Goldgeier, James M. and Michael McFaul. 1992. "A Tale of Two Worlds: Core and Periphery in the Post-Cold War Era." International Organization 46 (2): 467-491.

Gubler, Joshua R. and Joel Sawat Selway. 2012. "Horizontal Inequality, Crosscutting Cleavages, and Civil War.” Journal of Conflict Resolution 56 (2): 206-232.

Guimarães, Fernando Andresen. 2001. The Origins of the Angolan Civil War: Foreign Intervention and Domestic Political Conflict, 1961-76. Basingstoke, Hampshire: Palgrave Macmillan.

Hansen, Stig J. 2006. "Warlords and Peace Strategies: The Case of Somalia." Journal of Conflict Studies 23 (2): 57-78.

Hardt, Michael, and Antonio Negri. 2000. Empire. Cambridge, MA: Harvard University Press.

Hardt, Michael, and Antonio Negri. 2004. Multitude: War and Democracy in the Age of Empire. New York, NY: Penguin Books.

Herbst, Jeffrey. 1990. "War and the State in Africa." International Security 14 (4): $117-139$.

Hill, Walter W. 2009. "Reviewed Work(s): Rethinking the Economics of War: The Intersection of Need, Creed, and Greed by Cynthia J. Arnson and I. William Zartman." International Journal on World Peace 26 (1): 153-156. 
Hobbes, Thomas. 2010. Leviathan, or, The Matter, Forme, \& Power of a CommonWealth Ecclesiasticall and Civill [First Published in 1651; Reprint 2010]. (Rethinking the Western Tradition). New Heaven, CT: Yale University Press.

Hudson, Valerie M., Mary Caprioli, Bonnie Ballif-Spanvill, Rose McDermott, and Chad F. Emmett. 2009. "The Heart of the Matter: The Security of Women and the Security of States." International Security 33 (3): 7-45.

Ikenberry, G. John. 2010. “The Liberal International Order and Its Discontents.” Millennium 38 (3): 509-521.

Kelly, Liz. 2000. "Wars against Women: Sexual Violence, Sexual Politics and the Militarised State." In States of Conflict: Gender, Violence and Resistance, edited by Susie Jacobs, Ruth Jacobson, and Jennifer Marchbank, 45-65. London, UK: Zed Books.

Lacina, Bethany, and Nils Petter Gleditsch. 2005. "Monitoring Trends in Global Combat: A New Dataset of Battle Deaths." European Journal of Population/Revue Européenne de Démographie 21 (2-3): 145-166.

Lahai, John Idriss. 2015. "Gendering Conflict and Peace-Building in Sierra Leone." In Female Combatants in Conflict and Peace, edited by Seema Shekhawat, 132-148. Palgrave Macmillan UK. https://doi.org/10.1057/9781137516565_9.

Lahai, John Idriss. 2016a. Gender in Practice: Culture, Politics and Society in Sierra Leone. 14 vols. http://dx.doi.org/10.3726/b11126. Oxford, UK: Peter Lang Ltd.

Lahai, John Idriss. 2016b. "The International Responsibility to Protect and the Conflict in Darfur." In African Frontiers: Insurgency, Governance and Peacebuilding in Postcolonial States, edited by John Idriss Lahai and Tanya Lyons, 55-68. Abingdon, UK: Routledge.

Lahai, John Idriss, and Tanya Lyons. 2016. "The West African Warscapes: Rebe Factions, Insurgent Opportunism and State Governance." In African Frontiers: Insurgency, Governance and Peacebuilding in Postcolonial States, edited by John Idriss Lahai and Tanya Lyons, 17-30. Abingdon, UK: Routledge.

Le Billon, Philippe. 2001. "The Political Ecology of War: Natural Resources and Armed Conflicts.” Political Geography 20 (5): 561-584.

LeRiche, Matthew, and Matthew Arnold. 2013. South Sudan: From Revolution to Independence. Oxford, UK: Oxford University Press.

Lyons, Tanya. 2004. Guns and Guerilla Girls: Women in the Zimbabwean National Liberation Struggle. Asmara, Eritrea: Africa World Press.

Malone, David M. and Jake Sherman. 2005. "Economic Factors in Civil Wars: Policy Considerations." In Rethinking the Economics of War: The Intersection of Need, Creed, and Greed, edited by Cynthia J. Arnson and I. William Zartman, 234-256. Washington, DC: Woodrow Wilson Center Press.

Mamdani, Mahmood. 2001. When Victims Become Killers: Colonialism, Nativism, and the Genocide in Rwanda. New Jersey, NJ: Princeton University Press.

Marx, Karl. 1973. Karl Marx on Society and Social Change: With Selections by Friedrich Engels. Edited by Neil J. Smelser. Chicago, IL: University of Chicago Press.

Mazrui, Ali A. 1973. "The Lumpen Proletariat and the Lumpen Militariat: African Soldiers as a New Political Class.” Political Studies 21 (1): 1-12.

Mearsheimer, John. 2001. The Tragedy of Great Power Politics. New York, NY: Norton. Meintjes, Sheila, Meredeth Turshen, and Anu Pillay. 2001. The Aftermath: Women in Post-Conflict Transformation. London, UK: Zed Books.

Melber, Henning. 2002. "From Liberation Movements to Governments: On Political Culture in Southern Africa." African Sociological Review/Revue Africaine de Sociologie 6(1): 161-172. 
Miller, Sarah Clark. 2009. "Moral Injury and Relational Harm: Analyzing Rape in Darfur." Journal of Social Philosophy 40 (4): 504-523.

Minter, William. 1994. Apartheid's Contras: An Inquiry into the Roots of War in Angola and Mozambique. Johannesburg, SA: Witwatersrand University Press.

Mullins, Christopher W. 2009. “'He Would Kill Me with His Penis': Genocidal Rape in Rwanda as a State Crime." Critical Criminology 17 (1): 15-33.

Nafziger, E. Wayne, and Juha Auvinen. 2002. "Economic Development, Inequality, War, and State Violence." World Development 30 (2): 153-163.

O'Brien, Mary. 1989. "The Root of the Mandrake: Machiavelli and Manliness." In Reproducing the World: Essays in Feminist Theory, edited by Mary O'Brien, 103-127. Boulder, CO: Westview Press.

Østby, Gudrun. 2008. "Polarization, Horizontal Inequalities and Violent Civil Conflict." Journal of Peace Research 45 (2): 143-162.

Østby, Gudrun, Ragnhild Nordås and Jan Ketil Rød. 2009. "Regional Inequalities and Civil Conflict in Sub-Saharan Africa." International Studies Quarterly 53 (2): 301-324.

Parry, Benita. 1998. "Liberation Movements: Memories of the Future." Interventions: International Journal of Postcolonial Studies 1 (1): 45-51.

Pitcher, Anne, Mary H. Moran and Michael Johnston. 2009. "Rethinking Patrimonialism and Neopatrimonialism in Africa." African Studies Review 52 (1): 125-156.

Reno, William. 1999. Warlord Politics and African States. Boulder, CO: Lynne Rienner Publishers.

Riley, Patrick. 1982. Will and Political Legitimacy: A Critical Exposition of Social Contract Theory in Hobbes, Locke, Rousseau, Kant, and Hegel. Cambridge, MA: Harvard University Press.

Ruby Reid-Cunningham, Allison. 2008. "Rape as a Weapon of Genocide." Genocide Studies and Prevention 3 (3): 279-296.

Rummel, R. J. 1977. Understanding Conflict and War: Vol. 3: Conflict in Perspective Beverly Hills. Vol. 3 vols. Beverly Hills, California: Sage Publications Ltd.

Saccarelli, Emanuele. 2009. "The Machiavellian Rousseau: Gender and Family Relations in the Discourse on the Origin of Inequality." Political Theory 37 (4): 482-510.

Saxonhouse, Arlene W. 2004. "Niccolo Machiavelli: Women as Men, and Men as Women, and the Ambiguity of Sex." In Feminist Interpretations of Niccolò Machiavelli, edited by Maria J. Falco, 93-116. Pennsylvania, PA: Pennsylvania State University Press.

Scott, Straus. 2006. The Order of Genocide: Race, Power, and War in Rwanda. Ithaca, NY: Cornell University Press.

Shklar, Judith N. 1985. Men and Citizens: A Study of Rousseau's Social Theory. Paperback edition. Cambridge, UK: Cambridge University Press.

Silver, Victoria. 1996. "Hobbes on Rhetoric." In The Cambridge Companion to Hobbes, edited by Tom Sorell, 329-345. Cambridge, UK: Cambridge University Press.

Sivakumaran, Sandesh. 2007. "Sexual Violence against Men in Armed Conflict." European Journal of International Law 18 (2): 253-276.

Smith, Zeric Kay. 2000. "The Impact of Political Liberalisation and Democratisation on Ethnic Conflict in Africa: An Empirical Test of Common Assumptions." The Journal of Modern African Studies 38 (1): 21-39.

Solomon, Hussein. 2014. "Somalia's Al Shabaab: Clans vs Islamist Nationalism.” South African Journal of International Affairs 21 (3): 351-366.

Sorell, Tom, ed. 1996. Hobbes's Political Philosophy. Cambridge, UK: Cambridge University Press. 
Stewart, Frances, ed. 2016. Horizontal Inequalities and Conflict: Understanding Group Violence in Multiethnic Societies. Basingstoke, Hampshire: Palgrave Macmillan.

Sylvester, Christine. 1994. Feminist Theory and International Relations in a Postmodern Era. Vol. 32. Cambridge, UK: Cambridge University Press.

Themnér, Lotta, and Peter Wallensteen. 2011. "Armed Conflict, 1946-2010.” Journal of Peace Research 48 (4): 525-536.

Trenholm, Jill E., Pia Olsson, and Beth Maina Ahlberg. 2011. "Battles on Women's Bodies: War, Rape and Traumatisation in Eastern Democratic Republic of Congo." Global Public Health 6 (2): 139-152.

Uppsala Conflict Data Program (UCDP). 2013. "UCDP/PRIO Armed Conflict Dataset Codebook (Version4-2013)." Uppsala, Oslo: Centre for the Study of Civil Wars, International Peace Research Institute, Oslo (PRIO). www.pcr.uu.se/digitalAssets/167/ a_167198-f_codebook_ucdp_prio-armed-conflict-dataset-v4_2013.pdf.

Wallensteen, Peter, and Margareta Sollenberg. 1999. "Armed Conflict, 1989-98." Journal of Peace Research 36 (5): 593-606.

Waltz, Kenneth Neal. 2001. Man, the State, and War: A Theoretical Analysis. New York, NY: Columbia University Press.

Waugh, Colin M. 2004. Paul Kagame and Rwanda: Power, Genocide and the Rwandan Patriotic Front. Jefferson, NC: McFarland \& Company, Inc., Publishers.

Willett, Susan. 2005. "New Barbarians at the Gate: Losing the Liberal Peace in Africa." Review of African Political Economy 32 (106): 569-594.

World Bank. 2011. "Operationalizing the 2011 World Development Report: Conflict, Security, and Development." (Development Committee's Joint Ministerial Committee of the Borad of Governors of the Bank and the Fund on the Transfer of Real Resources to Developing Countries; DC2011-0003 (April 4). Washington, DC: World Bank. http:// siteresources.worldbank.org/DEVCOMMINT/Documentation/22884392/DC20110003\%28E\%29WDR2011.pdf.

Yule, William, Rune Stuvland, Florence K. Baingana, and Patrick Smith. 2004. "Children in Armed Conflict." In Trauma Interventions in War and Peace, edited by B. L. Green, M. L. Friedman, J. de Jong, S.D. Solomon, T.M. Keane, J. A. Fairbank, B. Donelan, and E Frey-Wouters, 217-242. Boston, MA: Springer.

Zartman, I. William. 2000. "Mediating Conflicts of Need, Greed, and Creed." Orbis 44 (2): 255-266.

Zolberg, Aristide R. 1968. "The Structure of Political Conflict in the New States of Tropical Africa." American Political Science Review 62 (1): 70-87. 


\section{Appendix 4: Calculation of the reconciliation words threshold}

$$
\begin{aligned}
& \frac{d B R D}{d R \operatorname{Ron}}=\sigma_{i}+2 \sigma_{i} \text { Rcon }=0 \\
& 69.522+2(-0.993) \text { Rcon }=0 \\
& 1.986 \text { Rcon }=69.522 \\
& \text { Rcon }=\frac{69.522}{1.986}=35.006
\end{aligned}
$$

where $B R D=$ battle-related deaths Rcon $=$ Reconciliation words

\section{Notes}

1 With the exception of Somalia, which, at the time, had no functional government as a result of the fighting between the forces of Fareer Aideed and Ali Mahdi.

2 For more on this, see www.sadc.int/sadc-secretariat/directorates/office-executivesecretary/organ-politics-defense-and-security/ (accessed July 28, 2018).

\section{References}

Asteriou, Dimitrios, and S. G. Hall. 2011. Applied Econometrics: A Modern Approach Using Eviews and Microfit. Basingstoke, UK: Palgrave Macmillan.

Bagge Laustsen, Carsten, and Ole Waever. 2000. "In Defence of Religion: Sacred Referent Objects for Securitization." Millennium 29 (3): 705-739.

Ballentine, Karen, and Jake Sherman, eds. 2003. The Political Economy of Armed Conflict: Beyond Greed and Grievance. Boulder, CO: Lynne Rienner Publishers.

Baltagi, Badi. 2008. Econometric Analysis of Panel Data. Chichester, UK: John Wiley \& Sons.

Balzacq, Thierry. 2005. "The Three Faces of Securitization: Political Agency, Audience and Context." European Journal of International Relations 11 (2): 171-201.

Balzacq, Thierry. 2010. "Enquiries into Methods: A New Framework for Securitization Analysis." In Securitization Theory: How Security Problems Emerge and Dissolve, edited by Thierry Balzacq, 45-68. Abingdon, UK: Routledge.

Balzacq, Thierry. ed. 2011. Securitization Theory: How Security Problems Emerge and Dissolve. Abingdon, UK: Routledge.

Bartlett, F. C. 1932. A Theory of Remembering: A Study in Experimental and Social Psychology. Cambridge, UK: Cambridge University Press.

Behrend, Heike. 1999. "Power to Heal, Power to Kill. Spirit Possession and War in Northern Uganda (1986-1994)." In Spirit Possession, Modernity, and Power in Africa, edited by Ute Luig and Heike Behrend, 20-33. Madison, WI: University of Wisconsin Press.

Bellamy, Alex J. and Ruben Reike. 2010. "The Responsibility to Protect and International Law." Global Responsibility to Protect 2 (3): 267-286.

Betancourt, Theresa S., Ivelina I. Borisova, Marie De la Soudiere, and John Williamson. 2011. "Sierra Leone's Child Soldiers: War Exposures and Mental Health Problems by Gender." Journal of Adolescent Health 49 (1): 21-28. 
Bleiker, Roland, and Emma Hutchison. 2008. "Fear No More: Emotions and World Politics." Review of International Studies 34 (S1): 115-135.

Cameron, Adrian Colin, and Pravin K. Trivedi. 2010. "Microeconometrics Using Stata." www.stata.com/stata-news/statanews.23.4.pdf.

Chime, Chimelu. 1977. Integration and Politics among African States: Limitations and Horizons of Mid-Term Theorizing. Uppsala: The Scandinavian Institute of African Studies.

Chomsky, Noam. 1957. Syntactic Structure. The Hague: Mounton Publishers. www.linguist. univ-paris-diderot.fr/ edunbar/ling499b_spr12/readings/syntactic_structures.pdf.

Cockburn, Cynthia. 2010. "Gender Relations as Causal in Militarization and War." International Feminist Journal of Politics 12 (2): 139-157.

Collier, Paul. 2000. "Rebellion as a Quasi-Criminal Activity." Journal of Conflict Resolution 44 (6): 839-853.

Collier, Paul, and Anke Hoeffler. 2004. "Greed and Grievance in Civil War." Oxford Economic Papers 56 (4): 563-595.

Crawford, Neta C. 2000. "The Passion of World Politics: Propositions on Emotion and Emotional Relationships.” International Security 24 (4): 116-156.

Deleuze, Gilles, and Michel Foucault. 1977. "Intellectuals and Power." In Language, Counter-Memory, Practice: Selected Essays and Interviews, edited by D. F. Bouchard, 205-17. Ithaca, NY: Cornell University Press.

Downes, William. 1998. Language and Society. Cambridge, UK: Cambridge University Press.

Doyle, Michael W. 2005. "Three Pillars of the Liberal Peace." American Political Science Review 99 (3): 463-466.

Dugdale, Eric, and Loramy Gerstbauer. 2017. "Forms of Justice in Aeschylus' Eumenides." Polis: The Journal for Ancient Greek Political Thought 34 (2): 226-250.

Fillmore, Charles J. 1976. "Frame Semantics and the Nature of Language." Annals of the New York Academy of Sciences 280 (1): 20-32.

Fisher, Kathryn Marie. 2015. Security, Identity, and British Counterterrorism Policy. Basingstoke, UK: Palgrave Macmillan.

Floyd, Rita. 2011. "Can Securitization Theory Be Used in Normative Analysis? Towards a Just Securitization Theory.” Security Dialogue 42 (4-5): 427-439.

Floyd, Rita. 2016. "Extraordinary or Ordinary Emergency Measures: What, and Who, Defines the 'Success' of Securitization?" Cambridge Review of International Affairs 29 (2): 677-694.

Foucault, Michel. 2005. "The Discourse on Language: From 'Truth and Power." "In Truth: Engagements across Philosophical Traditions, edited by José Medina and Wood, 315-335. Malden, MA: Blackwell Publishing.

Franke, Benedikt. 2009. Security Cooperation in Africa: A Reappraisal. Boulder, CO: FirstForumPress.

Galtung, Johan. 1987. "Language and War: Is There a Connection?" Current Research on Peace and Violence 10 (1): 2-6.

Gamson, William A. and Andre Modigliani. 1987. "The Changing Culture of Affirmative Action." In Research in Political Sociology, edited by Richard G. Braungart and Margaret M. Braungart, 137-77. Greenwich, CT: Jai Press.

Garfinkel, Michelle R. and Stergios Skaperdas, eds. 1996. The Political Economy of Conflict and Appropriation. Cambridge, UK: Cambridge University Press.

Gates, Scott. 2002. "Recruitment and Allegiance: The Microfoundations of Rebellion." Journal of Conflict Resolution 46 (1): 111-130. 
Gimenez-Salinas, Andrea. 2004. "New Approaches Regarding Private/Public Security." Policing and Society 14 (2): 158-174.

Gledhill, John. 2008. "Anthropology in the Age of Securitization." Annual Joel S. Kahn Lecture, Latrobe University. Melbourne. Australia. http://jg.socialsciences.manchester. ac.uk/Conferences/Anthropology $\% 20 \mathrm{in} \% 20$ the $\% 20 \mathrm{Age} \% 20 \mathrm{of} \% 20$ Securitization.pdf.

Goffman, Erving. 1974. Frame Analysis: An Essay on the Organization of Experience. Cambridge, MA: Harvard University Press.

Goldstein, Daniel M. 2016. "Some Thoughts on the Critical Anthropology of Security." Etnofoor, Humour 28 (1): 147-152.

Goodenough, Ward Hunt. 1981. Culture, Language, and Society. Menlo Park, CA: Benjamin-Cummings Publishing Company.

Hale, Katherine. 1998. "The Language of Cooperation: Negotiation Frames." Mediation Quarterly 16 (2): 147-162.

Hansen, Lene. 2011. "Theorizing the Image for Security Studies: Visual Securitization and the Muhammad Cartoon Crisis." European Journal of International Relations 17 (1): 51-74.

Hirshleifer, Jack. 1988. "The Analytics of Continuing Conflict.” Synthese 76 (2): 201-233.

Hirshleifer, Jack. 2001. The Dark Side of the Force: Economic Foundations of Conflict Theory. Cambridge, UK: Cambridge University Press.

Holbraad, Martin, and Morten Axel Pedersen, eds. 2013. Times of Security: Ethnographies of Fear, Protest and the Future. New York, NY: Routledge.

Holdcroft, David. 1991. Saussure: Signs, System and Arbitrariness. Cambridge, UK: Cambridge University Press.

Howard, Steve. 2012. "Towards Researching Peace." African Conflict \& Peacebuilding Review 2 (2): 1-4.

Huysmans, Jef. 2011. "What's in an Act? On Security Speech Acts and Little Security Nothings." Security Dialogue 42 (4-5): 371-383.

Jacobsen, Michael Hviid, and Soren Kristiansen. 2015. The Social Thought of Erving Goffman. Thousand Oaks, CA: Sage Publications.

Johnston, Hank, and Pamela E. Oliver. 2000. "What a Good Idea! Frames and Ideologies in Social Movement Research.” Mobilization: An International Quarterly 5 (1): 37-54.

Kaplow, Jeffrey M. 2015. "The Negotiation Calculus: Why Parties to Civil Conflict Refuse to Talk." International Studies Quarterly 60 (1): 38-46.

Ke, Changxia, Kai A. Konrad, and Florian Morath. 2013. "Brothers in Arms: An Experiment on the Alliance Puzzle." Games and Economic Behavior 77 (1): 61-76.

Kelsall, Tim. 2005. "Truth, Lies, Ritual: Preliminary Reflections on the Truth and Reconciliation Commission in Sierra Leone.” Human Rights Quarterly 27 (2): 361-391.

Keskinen, Suvi. 2017. "Securitized Intimacies, Welfare State and the 'Other' Family." Social Politics: International Studies in Gender, State \& Society 24 (2): 154-177.

Lacomba, Juan A., Francisco Lagos, Ernesto Reuben, and Frans van Winden. 2014. "On the Escalation and De-Escalation of Conflict." Games and Economic Behavior 86: 40-57.

Lakoff, George. 2016. "Language and Emotion.” Emotion Review 8 (3): 269-273.

Lane, Frederic C. 1958. "Economic Consequences of Organized Violence." The Journal of Economic History 18 (4): 401-417.

Lawrence Butler, C. T. and Amy Rothstein. 1987. On Conflict and Consensus: A Handbook on Formal Consensus Decisionmaking. Portland, ME: Food Not Bombs Publishing.

Léonard, Sarah, and Christian Kaunert. 2011. "Reconceptualizing the Audience in Securitization Theory." In Securitization Theory: How Security Problems Emerge and Dissolve, edited by Thierry Balzacq, 57-76. Abingdon, UK: Routledge. 
Lindquist, Kristen A. and Maria Gendron. 2013. "What's in a Word? Language Constructs Emotion Perception." Emotion Review 5 (1): 66-71.

Makoa, Francis K. 2005. "Managing Conflict in an Integrating Southern Africa: Peace, Security and Stability in Lieu of Democracy?" Monitoring Regional Integration in Southern Africa Yearbook 5 (1): 1-25.

McNay, Lois. 2013. Foucault and Feminism: Power, Gender and the Self. Cambridge, UK: Polity Press.

Mercer, Jonathan. 2006. "Human Nature and the First Image: Emotion in International Politics." Journal of International Relations and Development 9 (3): 288-303.

Miller, Kenneth E. and Andrew Rasmussen. 2010. "War Exposure, Daily Stressors, and Mental Health in Conflict and Post-Conflict Settings: Bridging the Divide between Trauma-Focused and Psychosocial Frameworks." Social Science \& Medicine 70 (1): 7-16.

Miller, Sarah Clark. 2009. "Moral Injury and Relational Harm: Analyzing Rape in Darfur." Journal of Social Philosophy 40 (4): 504-523.

Mollica, Richard F., B. Lopes Cardozo, Howard J. Osofsky, Beverley Raphael, Alastair Ager, and Peter Salama. 2004. "Mental Health in Complex Emergencies." The Lancet 364 (9450): 2058-2067.

Montgomery, Martin. 2008. An Introduction to Language and Society. London, UK: Routledge.

Nelson, Thomas E., Rosalee A. Clawson, and Zoe M. Oxley. 1997. "Media Framing of a Civil Liberties Conflict and Its Effect on Tolerance." American Political Science Review 91 (3): 567-583.

Nguyen, Minh Cong. 2010. "XTSUR: Stata Module to Estimate Seemingly Unrelated Regression Model on Unbalanced Panel Data." Statistical Software Components. https://ideas.repec.org/c/boc/bocode/s456953.html.

Odobo, Samuel Osagie, Amos Musa Andekin, and Kingsley Udegbunam. 2017. "Analysis of ECOWAS Institutional Framework for Conflict Management." Mediterranean Journal of Social Sciences 8 (6): 143-153.

Ong, Walter J. 1979. "Literacy and Orality in Our Times." Profession, 1-7.

Ong, Walter J. 1982. Orality and Literacy: The Technologizing of the Word. London, UK: Methuen \& Co. Ltd.

Ong, Walter J. 2015. Orality and Literacy. Abingdon, UK: Routledge.

Park, Augustine SJ. 2010. "Community-Based Restorative Transitional Justice in Sierra Leone." Contemporary Justice Review 13 (1): 95-119.

Pedersen, Duncan. 2002. "Political Violence, Ethnic Conflict, and Contemporary Wars: Broad Implications for Health and Social Well-Being." Social Science \& Medicine 55 (2): 175-190.

Pfeiffer, James. 2005. "Commodity Fetichismo, the Holy Spirit, and the Turn to Pentecostal and African Independent Churches in Central Mozambique." Culture, Medicine and Psychiatry 29 (3): 255-283.

Pruitt, Dean G. 2007. "Readiness Theory and the Northern Ireland Conflict." American Behavioral Scientist 50 (11): 1520-1541.

Putnik, Nenad, and Mladen Milošević. 2018. "Trends in Peace Research: Can Cyber Détente Lead to Lasting Peace?" In Handbook of Research on Examining Global Peacemaking in the Digital Age, edited by Bruce L. Cook, 1-18. Hershey, PA: IGI Global.

Romaine, Suzanne. 2000. Language in Society: An Introduction to Sociolinguistics. Oxford, UK: Oxford University Press. 
Salter, Mark B. 2008. "Securitization and Desecuritization: A Dramaturgical Analysis of the Canadian Air Transport Security Authority." Journal of International Relations and Development 11 (4): 321-349.

Sampson, Geoffrey. 1980. Schools of Linguistics: Competition and Evolution. London, UK: Hutchinson \& Co Ltd.

Schelling, Thomas C. 1960. The Strategy of Conflict. New York, NY: Oxford University Press.

Silver, Morris. 1974. "Political Revolution and Repression: An Economic Approach." Public Choice 17 (1): 63-71.

Skaperdas, Stergios. 1991. "Conflict and Attitudes toward Risk." The American Economic Review 81 (2): 116-120.

Stritzel, Holger. 2007. "Towards a Theory of Securitization: Copenhagen and Beyond." European Journal of International Relations 13 (3): 357-383.

Summerfield, Derek. 2002. "Effects of War: Moral Knowledge, Revenge, Reconciliation, and Medicalised Concepts of 'Recovery.'" BMJ: British Medical Journal 325 (7372): 1105 .

Sylvester, Christine. 1994. Feminist Theory and International Relations in a Postmodern Era. Vol. 32. Cambridge, UK: Cambridge University Press.

Taurek, Rita. 2006. "Critical Approaches to Security: Telling the Story of Securitization Theory." In Proceedings of the Central and Eastern European Studies Association Convention, 25-26.

Torres-Reyna, Oscar. 2007. "Panel Data Analysis Fixed and Random Effects Using Stata (v. 4.2)." Data \& Statistical Services, Princeton University. https://pdfs.semanticscholar. org/f70f/9754bc51b1eb2e74dc7dc4e47549910730ed.pdf.

Vuori, Juha A. 2008. "Illocutionary Logic and Strands of Securitization: Applying the Theory of Securitization to the Study of Non-Democratic Political Orders." European Journal of International Relations 14 (1): 65-99.

Watson, Scott. 2011. “The 'Human' as Referent Object? Humanitarianism as Securitization." Security Dialogue 42 (1): 3-20.

Whitrow, Gerald James, and Marlene P. Soulsby. 2003. What Is Time? Oxford, UK: Oxford University Press.

Williams, Michael C. 2003. "Words, Images, Enemies: Securitization and International Politics.” International Studies Quarterly 47 (4): 511-531.

Zartman, I. William. 1989. Ripe for Resolution: Conflict and Intervention in Africa. 2nd edition. Oxford, UK: Oxford University Press. 
Finally, child labor in SSA includes some of the most exploitative forms, with some children trapped in commercial sex exploitation (Côte d'Ivoire, Liberia, Tanzania, Nigeria, Cameroon, Zimbabwe and in some unlisted countries); others forcibly recruited into non-state armed groups; and yet others dealing in illicit drugs. These forms of child labor are also mainly driven by poverty, but their implications for society are of even deeper concern. Such children are more likely to die early or become physically incapacitated, stripping the country of the potential benefits from their labor, or to contract diseases that make them weaker and, thus, less productive members of society. Those who survive such activities physically unscathed may end up becoming security threats to their immediate social environments and to the country at large. Threats to political security is a characteristic of state fragility, and curbing such threats diverts economic resources that could have been invested in productive sectors of the economy. Given the strong link between child labor and fragility, we advocate that child labor should be given much attention among the fragility indicators.

\section{References}

Abdul-Mumuni, Abdallah, Bhasin K. Vijay, and Obeng K. Camara. 2018. "Remittances and Child Labour in Ghana: Does the Gender of the Household Head Matter?" Development Southern Africa 36 (1): 1-16.

Acaroğlu, Hakan, and Erol Kutlu. 2015. "The Human Capital Vicious Cycle Created by the Child Labor Issue in Turkey." Journal of Business and Economics, 500.

Admassie, Assefa. 2002. "Explaining the High Incidence of Child Labour in SubSaharan Africa." African Development Review 14 (2): 251-275.

Banerjee, Abhijit, and Sendhil Mullainathan. 2010. "The Shape of Temptation: Implications for the Economic Lives of the Poor." National Bureau of Economic Research. www.nber.org/papers/w15973.

Basu, Kaushik, and Pham Hoang Van. 1998. "The Economics of Child Labor.” American Economic Review, 412-427.

Basu, K., Das, S., and Dutta, B., 2010. "Child Labor and Household Wealth: Theory and Empirical Evidence of an Inverted-U." Journal of Development Economics 91 (1): 8-14. Bauer, Peter T. 1965. "The Vicious Circle of Poverty." Weltwirtschaftliches Archiv, 4-20. Bertocchi, Graziella, and Andrea Guerzoni. 2012. "Growth, History, or Institutions: What Explains State Fragility in Sub-Saharan Africa?” Journal of Peace Research 49 (6): 769-783.

Bhaskar, Venkataraman, and Bishnupriya Gupta. 2012. "Parental Altruism and Child Labor: Examining the Historical Evidence from the United States." Cliometrica 6 (3): 249-266.

Bolton, Charles D. 1981. "Some Consequences of the Meadian Self." Symbolic Interaction 4 (2): 245-259.

Brown, Drusilla K., Alan V. Deardorff, and Robert Mitchell Stern. 2002. The Determinants of Child Labor: Theory and Evidence. School of Public Policy, University of Michigan. www.academia.edu/download/33242469/child_labor_as.pdf.

Coon, Michael. 2016. "Remittances and Child Labor in Bolivia." IZA Journal of Migration 5 (1): 1. 


\section{Child labor}

CSA and ILO. 2018. "Ethiopia National Child Labour Survey 2015." Central statistical Agency (CSA) and International Labour Organization (ILO). www.ilo.org/ipec/Infor mationresources/WCMS_IPEC_PUB_28475/lang-en/index.htm.

Dehejia, Rajeev H. and Roberta Gatti. 2005. "Child Labor: The Role of Financial Development and Income Variability across Countries." Economic Development and Cultural Change 53 (4): 913-931.

Dumas, Christelle. 2007. "Why Do Parents Make Their Children Work? A Test of the Poverty Hypothesis in Rural Areas of Burkina Faso." Oxford Economic Papers. http:// oep.oxfordjournals.org/content/early/2007/01/06/oep.gp1031.short.

Edmonds, Eric V. 2008. Defining Child Labour: A Review of the Definitions of Child Labour in Policy Research. International Programme on the Elimination of Child Labour (IPEC), International Labour Organization.

European Communities. 2009. "Overcoming Fragility in Africa: Forging a New European Approach.” Robert Schuman Centre for Advanced Studies, European University Institute, San Domenico di Fiesole.

Faria, Cassandra Fernandes. 2010. "Why Is Child Labour Detrimental for Children?" Nurture, Aga Khan University, Institute for Educational Development, Karachi, no. 9: 18.

Ferreira, Ines Afonso Roque. 2015. "Defining and Measuring State Fragility: A New Proposal.” In, 39. Berkeley, CA. http://cega.berkeley.edu/assets/miscellaneous_files/109

ABCA_2015_Ines_Ferreira_Defining_and_measuring_state_fragility_A_ A new_pro posal_May15.pdf.

Frempong, Raymond Boadi, and David Stadelmann. 2018. "The Effect of Food Price Changes on Child Labour: Evidence from Uganda." The Journal of Development Studies 55 (7): 1-16.

GSS. 2003. "Ghana Child Labour Survey."

GSS. 2014. "Ghana Living Standards Survey Round 6 (GLSS 6): Child Labour Report." Ghana Statistical Service, Accra. www.statsghana.gov.gh/docfiles/glss6/GLSS6_Labour\% 20Force\%20Report.pdf.

Hussain, Mahmood, and Keith E. Maskus. 2003. "Child Labour Use and Economic Growth: An Econometric Analysis.” The World Economy 26 (7): 993-1017.

Ilahi, Nadeem, Peter F. Orazem, and Guilherme Sedlacek. 2009. "How Does Working as a Child Affect Wages, Income, and Poverty as an Adult?" In Child Labor and Education in Latin America, 87-101. Springer.

ILO. 2004. Child Labour: A Textbook for University Students. Geneva: International Labour Office.

ILO. 2011. Children in Hazardous Work: What We Know, What We Need to Do. Geneva: International Programme on the Elimination of Child Labour (IPEC), International Labour Office.

ILO. 2017a. "Global Estimates of Child Labour: Results and Trends, 2012-2016." Geneva. www.ilo.org/wcmsp5/groups/public/-dgreports/-dcomm/documents/publication/wcms 575499.pdf.

ILO. 2017b. "Global Estimates of Modern Slavery and Child Labour." ILO. www.ilo.org/ wcmsp5/groups/public/@ed_norm/@ipec/documents/publication/wcms_597869.pdf.

Jensen, Peter, and Helena Skyt Nielsen. 1997. "Child Labour or School Attendance? Evidence from Zambia.” Journal of Population Economics 10 (4): 407-424.

Kambhampati, Uma S. and Raji Rajan. 2006. "Economic Growth: A Panacea for Child Labor?" World Development 34 (3): 426-445.

Kindleberger, Charles Poor. 1958. Economic Development. New York, NY: McGraw Hill. 
Knaul, Felicia Marie. 2001. "The Impact of Child Labor and School Dropout on Human Capital: Gender Differences in Mexico." The Economics of Gender in Mexico: Work, Family, State, and Market, 46-84.

Koomson, Isaac. 2017. "Examining Child Labour and Parental Altruism from the RuralUrban Divide: Extending the Inverted-U Empirics." NESRA - WP/17/003. http://nesranet work.com/admin/images/pdf/20170421043933child\%20labour\%20and\%20parental\%20 altruism \%20from\%20the\%20rural-urban\%20divide.pdf.pdf.

Koomson, Isaac, and Simplice A. Asongu. 2016. "Relative Contribution of Child Labour to Household Farm and Non-Farm Income in Ghana: Simulation with Child's Education." African Development Review 28 (1): 104-115.

Kruger, Diana I. 2007. "Coffee Production Effects on Child Labor and Schooling in Rural Brazil." Journal of Development Economics 82 (2): 448-463.

Lima, Luiz Renato, Shirley Mesquita, and Marianne Wanamaker. 2015. "Child Labor and the Wealth Paradox: The Role of Altruistic Parents." Economics Letters 130: 80-82.

Lopez-Calva, Luis F. 2001. "Child Labor: Myths, Theories and Facts." Journal of International Affairs, 59-73.

NBS and ILO. 2016. "Tanzania National Child Labour Survey 2014: Analytical Report." International Labour Organization (ILO) and the Tanzania National Bureau of Statistics (NBS). ttp://www.ilo.org/ipec/Informationresources/WCMS_IPEC_PUB_28475/langen/index.htm.

Ncube, Mthuli, and Basil Jones. 2013. "Drivers and Dynamics of Fragility in Africa." African Development Bank, Africa Economic Brief 4 (5): 1-16.

Neumayer, Eric, and Indra De Soysa. 2005. "Trade Openness, Foreign Direct Investment and Child Labor." World Development 33 (1): 43-63.

Nurkse, Ragnar. 1953. Problems of Capital Formation in Underdeveloped Countries. Oxford: Oxford University Press.

Nurkse, Ragnar. 1957. Problemas Da Formação de Capital Em Países Subdesenvolvidos. Rio de Janeiro: Editora Civilização Brasileira.

Pörtner, Claus Chr. 2001. "Children as Insurance." Journal of Population Economics 14 (1): 119-136.

Ray, Ranjan. 2002. "The Determinants of Child Labour and Child Schooling in Ghana." Journal of African Economies 11 (4): 561-590.

Rosati, Furio Camillo, Zafiris Tzannatos, and others. 2003. "Child Work: An Expository Framework of Altruistic and Non-Altruistic Models." The World Bank. http://ideas. repec.org/p/wbk/hdnspu/25984.html.

UCW. 2017. "Understanding Trends in Child Labour." UCW Working Paper Series, Rome. www.ucw-project.org/attachment/04122017609Understanding_child_labour_ trends.pdf.

Uganda, B. O. S. 2003. Uganda National Household Survey, 2005/2006: Report on the Socioeconomic Survey. Entebbe, Uganda: Uganda BOS.

United Nations. 2015. "Transforming Our World: The 2030 Agenda for Sustainable Development." 2015. www.un.org/ga/search/view_doc.asp?symbol=A/RES/70/1\&Lang=E.

USDOL. 2017. "2016 Findings on the Worst Forms of Child Labour." Bureau of International Labour Affairs, U.S. Department of Labour. https://businessandhumanrights. uconn.edu/wp-content/uploads/sites/1850/2017/11/US-Dept-of-Labor-2016-WorstForms-of-Child-Labor.pdf.

Watson, Rod. 2010. "Symbolic Interactionism." Society and Language Use 7: 304-313.

World Bank. 2015. “'World Development Indicators', World Bank Publications.” www. gopa.de/fr/news/world-bank-release-world-development-indicators-2015. 
compulsory primary education) and the International Bureau of the U.S. Department of Labor (on the claim of criminal laws and enforcement mechanism against the worst forms of child labor, ${ }^{11}$ especially commercial sex work).

It is evident that there are more similarities than variations across the select country case studies in the processes of framing interventions. Local ownership of the institutional framework is emphasized. There are also multidimensional formulations of, and interventions against, vulnerability framing in risk management. Vulnerability has attracted five frames of formulation: the social (cultural), medical, educational, economic and legal. We did not desegregate the social and the education frames given the compulsory nature of one (formal education) and the spatialized non-compulsory nature of the other (culture-centric informal education). Concerning the medical intervention frame, while there is ambiguity regarding the possibility of defining child labor medically, the five national plans hold as sacrosanct the prioritization of medical interventions targeting children (especially girls) with the aim of mitigating early childhood pregnancy and the spread of sexually transmitted diseases. Another area of similarity is in the legal frameworks' source of legitimacy. While they are adopted by the national parliaments of these countries, our observations reveal that they owe their direction to the international and regional conventions and norms that underpin them. This, we suggest, will lead to the strengthening of the legal frame against cultural relativist objectionsthat is, if the political and social pull and push factors (such as the political misuse of identity politics) that give cultural belief systems political relevance are controlled. Framing of intervention based on the political preferences of external donor communities is not evident in the national plans, but there is evidence in the national policies of Kenya and Tanzania that the social sensitivities of international non-governmental organizations (INGOs) sway the framing of interventions. These similarities of frames could serve as a platform for the construction of a secure regional child protection database for the exchange of ideas and the development of a regional child offender registry system.

\section{Notes}

1 This day, which is celebrated every June 16, was developed in 1991 to honor the children who took part and died during the Soweto Uprising in Apartheid South Africa in 1979 (see, Rwezaura 1998, 85).

2 Between 2010 and 2018, however, only four additional countries ratified the Charter.

3 ACHPR Newsletter, title: "Ratification Table: African Charter on the Rights and Welfare of the Child." www.achpr.org/instruments/child/ratification/ (accessed June 10, 2018).

4 U.S. Department of Labor's Bureau of International Labor (BIL). 2016 Findings on the Worst Forms of Child Labour. Bureau of International Labour Affairs, U.S. Department of Labour. Retrieved from www.dol.gov/sites/default/files/documents/ ilab/reports/child-labor/findings/TDAMagazine.pdf.

5 The Tanzania National Plan goes on to extend the definition of poverty to include the lack of psychosocial support for the child: 
Child poverty, which is the deprivation of a range of both material and social supports and services that are considered essential to ensure children's well-being is inadequately addressed in the implementation of the existing policies. In essence, social protection measures must take into consideration the multi-dimensional and interrelated nature of child poverty and vulnerability. This includes addressing issues of social exclusion, which are currently not adequately addressed by the existing social insurance measures through the provision of the [unrestricted] cash and in-kind transfers to the Most Vulnerable Children (MVC) and their caregivers. Social policy and provisioning in Tanzania does not address inequalities and enhance access to basic services of all children and adolescents; mitigation of poverty on families; strengthening of families in their childcare role and providing special services to children who live outside a family environment. This is mainly due to the fact social provisioning is not statutorily guaranteed.

(Government of Tanzania 2009, 6)

6 For more on the historical constructions of the feminine psychosexual development in Freudian theory, see Zenia Odes Fliegel (1973).

7 For more on the inventory model for examining Erikson's stages of psychosocial development see, Doreen A. Rosenthal, Ross M. Gurney and Susan M. Moore (1981).

8 For more on Piaget's theory of cognitive and affective development: Foundations of constructivism, see Barry J. Wadsworth (1996).

9 For more on Bowlby's theory see, The Handbook of Attachment: Theory, Research, and Clinical Applications, edited by Jude Cassidy and Phillip R. Shaver (1999).

10 For more on the contributions of Vygotsky's sociocultural theory on social relations, see Alex Kozulin et al. (2003).

11 We observe that, the national plans did not treat the crisis of child labor the same way it treats incidences like armed insurgency, pandemic, famine and flooding. We believe this did contribute to creating the missing link that have made it less likely for to the crisis of child labor to be included as a stand-alone indicator of state fragility.

\section{References}

ACERWC (African Committee of Experts on the Rights and Welfare of the Child). 2018a. "Concept Note Day of the African Child 2018 - Leave No Child Behind for Africa's Development." An Africa Fit for Children. www.acerwc.org/download/ concept-note-day-of-the-african-child-2018/?wpdmdl=10329.

ACERWC (African Committee of Experts on the Rights and Welfare of the Child). 2018b. "Day of the African Child 2018." 2018. www.acerwc.org/ourevents/day-of-theafrican-child-2018/.

African Union. 2016. African's Agenda for Children 2040: Fostering an Africa Fit for Children. Addis Ababa, Ethiopia: African Union (AU). https://au.int/sites/default/files/ newsevents/agendas/africas_agenda_for_children-english.pdf.

Bass, Loretta Elizabeth. 2004. Child Labor in Sub-Saharan Africa. Boulder, CO: Lynne Rienner Publishers.

Bryceson, Deborah Fahy. 2006. "Fragile Cities: Fundamentals of Urban Life in East and Southern Africa." In African Urban Economies: Viability, Vitality or Vitiation?, edited by Deborah Fahy Bryceson and Deborah Potts, 3-38. New York, NY: Palgrave Macmillan.

Cassidy, Jude, and Phillip R. Shaver, eds. 1999. Handbook of Attachment: Theory, Research, and Clinical Applications. New York, NY: The Guilford Press. 
Chauvet, Lisa, and Paul Collier. 2008. "What Are the Preconditions for Turnarounds in Failing States?" Conflict Management and Peace Science 25 (4): 332-348.

Committee on Economic, Social and Cultural Rights. 2000. General Comment 14, The Right to the Highest Attainable Standard of Health (Twenty-Second Session, 2000) [Reprinted in Compilation of General Comments and General Recommendations Adopted by Human Rights Treaty Bodies, U.N. Doc. HRI/GEN/1/Rev.6 at 85 (2003)]. http://hrlibrary.umn.edu/gencomm/escgencom14.htm.

Day, Jeanne D. 1983. "The Zone of Proximal Development." In Cognitive Strategy Research, vol 3, issue No 1, 155-175. Springer.

Elu, Juliet. 2000. "Human Development in Sub-Saharan Africa: Analysis and Prospects for the Future." Journal of Global South Studies 17 (2): 53.

Fliegel, Zenia Odes. 1973. "Feminine Psychosexual Development in Freudian Theory: A Historical Reconstruction.” The Psychoanalytic Quarterly 42 (3): 385-408.

Freeman, Michael. 2007. Article 3: The Best Interests of the Child. Leiden, The Netherlands: Martinus Nijhoff Publishers.

French, J. R. and Bertram Raven. 1959. "The Bases of Social Power." Classics of Organization Theory 7: 311-320.

Government of Cameroon. 2013. Plan d'Action National Pour l'Elimination Des Pires Formes de Travail Des Enfants Au Cameroun (PANETEC) [The National Plan of Action to Combat Child Labor and Trafficking in Children] (2014-2016). Yaoundé, Cameroon: Ministere du Travail et de la Securite Sociale (MINTSS).

Government of Ghana, Ministry of Employment and Labour Relations (MELR). 2016. The National Place of Action (Phase II) for the Elimination of the Worst Forms of Child Labor in Ghana (2017-2012: Towards Achieving Sustainable Development Goal (SDG) 8.7. Accra, GH: Ministry of Employment and Labour Relations (MELR), Government of Ghana. www.unicef.org/ghana/NPA_(II)_EWFCL.pdf.

Government of Tanzania. 2009. National Action Plan for the Elimination of Child Labor. Arushia, TZ: Ministry of Labor, Employment and Youth Development. www.ilo.org/ dyn/natlex/docs/MONOGRAPH/94604/111054/F347421111/TZA94604.pdf.

Grimm, Michael, Kenneth Harttgen, Stephan Klasen, and Mark Misselhorn. 2008. "A Human Development Index by Income Groups.” World Development 36 (12): 2527-2546. Harris, Gordon. 1994. The Organization of African Unity. Vol. 7. Oxford, UK: Clio Press Ltd. Invernizzi, Antonella. 2008. "Everyday Lives of Working Children and Notions of Citizenship." In Children and Citizenship, edited by Antonella Invernizzi and Jane Williams, London: Springer, 131-142.

Kaime, Thoko. 2009. The African Charter on the Rights and Welfare of the Child: A Socio-Legal Perspective. Pretoria, South Africa: Pretoria University Press.

Kozulin, Alex, Boris Gindis, Vladimir S. Ageyev, and Suzanne M. Miller, eds. 2003. Vygotsky's Educational Theory in Cultural Context. Cambridge University Press.

Langlois, Anthony. 2005. "International Covenant on Civil and Political Rights (ICCPR)." In Encyclopedia of International Relations and Global Politics, edited by Martin Griffiths, 416-418. Abingdon, UK: Routledge.

Lundy, Laura. 2007. “'Voice' Is Not Enough: Conceptualising Article 12 of the United Nations Convention on the Rights of the Child." British Educational Research Journal 33 (6): 927-942.

Maluwa, Tiyanjana. 2012. "Ratification of African Union Treaties by Member States: Law, Policy and Practice." Melbourne Journal of International Law 636 13: 1-49.

Nilsson, Ann-Charlotte. 2013. Children and Youth in Armed Conflict. Leiden, The Netherlands: Martinus Nijhoff Publishers. 


\section{Child labor}

Ofodile, Uche Ewelukwa. 2010. "Universal Declaration of Human Rights and the African Child Today: Progress or Problems." American University International Law Review 25 (37): 37-76.

Okyere, Samuel. 2013. “Are Working Children's Rights and Child Labour Abolition Complementary or Opposing Realms?” International Social Work 56 (1): 80-91.

Organization of African Unity (OAU). 1990. African Charter on the Rights and Welfare of the Child (1990). http://hrlibrary.umn.edu/africa/afchild.htm.

Potts, Deborah. 2007. The State and the Informal in Sub-Saharan African Urban Economies: Revisiting Debates on Dualism (Working Paper No. 18 - Cities and Fragile States). Working Paper. London, UK: LSE Development Studies Institute. https:// assets.publishing.service.gov.uk/media/57a08beee5274a31e0000ea6/wp18.2.pdf.

Rosenthal, Doreen A., Ross M. Gurney, and Susan M. Moore. 1981. "From Trust on Intimacy: A New Inventory for Examining Erikson's Stages of Psychosocial Development." Journal of Youth and Adolescence 10 (6): 525-537.

Rwezaura, Bart. 1998. "The Duty to Hear the Child: A View from Tanzania." In Law, Culture, Tradition, and Children's Rights in Eastern and Southern Africa, edited by Welshman Ncube, 57-94. Aldershot, UK: Ashgate Publishing, Ltd.

UN General Assembly. 1966. "International Covenant on Economic, Social and Cultural Rights." United Nations, Treaty Series 993 (3).

UNDP, United Nations Development Programme. 2017. Human Development Report 2016: Human Development for Everyone. United Nations Publications. New York, NY: United Nations Development Programme. http://hdr.undp.org/en/2016-report.

U.S. Department of Labor, International Labor Affairs Bureau. 2016. Technical Cooperation Project Summary - Wekeza: Wezesha Ustawi, Endeleza Kiwango Cha Elimu Kuzia Ajira Kwa Watoto/Invest: Supporting Livelihoods And Developing Quality Education To Stop Child Labor. Washington, DC: U.S. Department of Labor. www.dol.gov/ilab/projects/summaries/Tanzania_WEKEZA.pdf.

U.S. Department of Labor, International Labor Affairs Bureau. 2017a. 2016 Findings on the Worst Forms of Child Labour (Cameroon). Washington, DC: U.S. Department of Labor. Retrieved from www.dol.gov/sites/default/files/images/ilab/child-labor/Cameroon2016.pdf.

U.S. Department of Labor, International Labor Affairs Bureau. 2017b. 2016 Findings on the Worst Forms of Child Labour (Ghana). Washington, DC: U.S. Department of Labor. Retrieved from www.dol.gov/sites/default/files/images/ilab/child-labor/2016 Ghana.pdf.

U.S. Department of Labor, International Labor Affairs Bureau. 2017c. "2016 Findings on the Worst Forms of Child Labour (Kenya)." Washington, DC: U.S. Department of Labor. Retrieved from www.dol.gov/sites/default/files/images/ilab/child-labor/ Kenya2016.pdf.

U.S. Department of Labor, International Labor Affairs Bureau. 2017d. "2016 Findings on the Worst Forms of Child Labour (Zimbabwe)." Washington, DC: U.S. Department of Labor. www.dol.gov/agencies/ilab/resources/reports/child-labor/zimbabwe.

Van Bueren, Geraldine. 1998. International Documents on Children. The Hague, The Netherland: Martinus Nijhoff Publishers.

Wadsworth, Barry J. 1996. Piaget's Theory of Cognitive and Affective Development: Foundations of Constructivism. White Plains, NY: Longman Publishing. 
activities, and the income they generate, function as risk-coping strategies when other socioeconomic activities have been disrupted by the onset of a pandemic. Non-farm economic activities are also unaffected by, or less vulnerable to, the season-dependence of farming activities and therefore offer more resilient income streams. Wholly agricultural households, in contrast, are highly vulnerable to disruption during specific seasons and struggle to recover financially as income-generating activities are season-limited. Another recommendation is that governments and civil society organization direct increased attention-in the form of relief and aid - to rural and satellite communities during pandemics, as these households are at the greatest risk of becoming food during outbreaks of disease such as EVD.

\section{Note}

1 African Development Bank (AFDB), Government of Sierra Leone (GoSL), World Bank (WB), World Food Programme (WFP), European Union (EU), Food and Agriculture Organization of the United Nations (FAO).

\section{References}

Adem, M., E. Tadele, H. Mossie, and M. Ayenalem. 2018. "Income Diversification and Food Security Situation in Ethiopia: A Review Study.” Cogent Food \& Agriculture 4 (1): 1513354.

African Development Bank (AFDB), Government of Sierra Leone (GSL), World Bank (WB), World Food Programme (WFP), European Union (EU) and UN Food and Agriculture Organization (FAO). 2015. State of Food Security in Sierra Leone 2015: Comprehensive Food Security and Vulnerability Analysis. Retrieved from https://reliefweb. int/sites/reliefweb.int/files/resources/wfp288316.pdf.

Agbola, P. O., D. O. Awotide, A. E. Ikpi, P. Kormawa, V. O. Okoruwa, and D. A. Babalola. 2008. Effect of Income Diversification Strategies on Food Insecurity Status of Farming Households in Africa: Result of Analysis from Nigeria. Result of Analysis from Nigeria (No. 725-2016-49415).

Agyeman, B. A. S., S. Asuming-Brempong, and E. E. Onumah. 2014. "Determinants of Income Diversification of Farm Households in the Western Region of Ghana." Quarterly Journal of International Agriculture 53 (1): 55-72.

Alinovi, L., G. Hemrich, and L. Russo. 2007. Addressing Food Insecurity in Fragile States: Case Studies from the Democratic Republic of the Congo, Somalia and Sudan. Rome: Citeseer.

Asteriou, D., and S. G. Hall. 2011. Applied Econometrics. New York, NY: Palgrave Macmillan.

Baltagi, B. 2008. Econometric Analysis of Panel Data, 4th edn. Chichester: John Wiley \& Sons.

Beavers, A. S., J. W. Lounsbury, J. K. Richards, S. W. Huck, G. J. Skolits, and S. L. Esquivel. 2013. "Practical Considerations for Using Exploratory Factor Analysis in Educational Research." Practical Assessment, Research \& Evaluation 18 (6): 1-13.

Cameron, A. C., and P. K. Trivedi. 2010. Microeconometrics Using Stata. Retrieved from www.stata.com/stata-news/statanews.23.4.pdf. 


\section{Food (in)security}

De Waal, A., and A. Whiteside. 2003. "New Variant Famine: AIDS and Food Crisis in Southern Africa." The Lancet 362 (9391), 1234-1237.

FAO. 2000. The State of Food Insecurity in the World 2000. Rome: Food and Agriculture Organisation. Retrieved from www.fao.org/FOCUS/E/SOFI00/img/sofirep-e.pdf.

FAO. 2017. Regional Overview of Food Security and Nutrition in Africa 2017. The Food Security and Nutrition-Conflict Nexus: Building Resilience for Food Security, Nutrition and Peace. Accra: Food and Agriculture Organization of the United Nations. Retrieved from www.fao.org/3/a-i7967e.pdf.

Figuié, M. 2016. Impact of the Ebola Virus Disease Outbreak on Market Chains and Trade of Agricultural Products in West Africa. Report for FAO REOWA (Resilience, Emergencies and Rehabilitation in West Africa). Food and Agriculture Organization of the United Nations.

Greene, W. 2004. "The Behaviour of the Maximum Likelihood Estimator of Limited Dependent Variable Models in the Presence of Fixed Effects." The Econometrics Journal 7 (1), 98-119.

Himelein, K., M. Testaverde, A. Turay, and S. Turay. 2015. The Socio-Economic Impacts of Ebola in Sierra Leone (Round 3). Retrieved from www.worldbank.org/content/dam/ Worldbank/document/Poverty\%20documents/Socio-Economic\%20Impacts $\% 20$ of $\% 20$ Ebola\%20in\%20Sierra\%20Leone,\%20April\%2015\%20(final).pdf

Himmelgreen, D. A., N. Romero-Daza, D. Turkon, S. Watson, I. Okello-Uma, and D. Sellen. 2009. "Addressing the HIV/AIDS_Food Insecurity Syndemic in Sub-Saharan Africa." African Journal of AIDS Research 8 (4): 401-412.

Jolliffe, I. T. 2002. "Principal Components in Regression Analysis." Principal Component Analysis. Springer Series in Statistics, 167-198.

Kaiser, H. F. 1974. An Index of Factorial Simplicity. Psychomertrika 39: 13-36.

Lahai, J. I. 2016. Gender in Practice: Culture, Politics and Society in Sierra Leone (Vols. 1-14). Oxford: Peter Lang Ltd.

Lahai, J. I. 2017. The Ebola Pandemic in Sierra Leone: Representations, Actors, Interventions and the Path to Recovery. Basingstoke: Palgrave Macmillan.

Maxwell, D. G. 1996. "Measuring Food Insecurity: The Frequency and Severity of 'Coping Strategies'." Food Policy 21 (3): 291-303.

Mentamo, M., and N. R. Geda. 2016. "Livelihood Diversification under Severe Food Insecurity Scenario among Smallholder Farmers in Kadida Gamela District, Southern Ethiopia." Kontakt 18 (4): e258-e264.

Naysmith, S., A. de Waal, and A. Whiteside. 2009. "Revisiting New Variant Famine: The Case of Swaziland." Food Security 1 (3): 251-260.

Nguyen, M. C. 2010. XTSUR: Stata Module to Estimate Seemingly Unrelated Regression Model on Unbalanced Panel Data. Statistical Software Components. Retrieved from https://ideas.repec.org/c/boc/bocode/s456953.html.

Oldewage-Theron, W. H., E. G. Dicks, and C. E. Napier. 2006. "Poverty, Household Food Insecurity and Nutrition: Coping Strategies in an Informal Settlement in the Vaal Triangle, South Africa." Public Health 120 (9): 795-804.

Richards, P. 1996. Fighting for the Rainforest: War, Youth and Resources in Sierra Leone. Oxford: James Currey.

Richards, P. 2005. "To Fight or to Farm? Agrarian Dimensions of the Mano River Conflicts (Liberia and Sierra Leone)." African Affairs 104 (417): 571-590.

Shariff, Z. M., and G. L. Khor. 2008. Household Food Insecurity and Coping Strategies in a Poor Rural Community in Malaysia. Nutrition Research and Practice 2 (1): 26-34. 
Smillie, I., L. Gberie, and R. Hazleton. 2000. The Heart of the Matter: Sierra Leone Diamonds and Human Security. Partnership Africa Canada Ottawa. Retrieved from www. pacweb.org/Documents/diamonds_KP/heart_of_the_matter-full-2000-01-eng.doc.

Torres-Reyna, O. 2007. Panel Data Analysis Fixed and Random Effects Using Stata (v. 4.2). Data and Statistical Services, Princeton University. Retrieved from https://pdfs. semanticscholar.org/f70f/9754bc51b1eb2e 74dc7dc4e47549910730ed.pdf.

UNDP. 2015. Socio-Economic Impact of Ebola Virus Disease in West Africa: A Call For National and Regional Containment, Recovery and Prevention. United Nations Development Group. Retrieved from https://reliefweb.int/sites/reliefweb.int/files/resources/ ebola-west-africa.pdf.

UNECA. 2014. The Socio-Economic Impacts of Ebola Virus Disease (EVD) in Africa. United Nations Economic Commission for Africa. Retrieved from www.uneca.org/ sites/default/files/PublicationFiles/eca_ebola_report_final_eng.pdf.

WFP and VAM. 2015. Food Insecurity on the Rise as Ebola Abates: Application of Shock Impact Simulation Model (SISMod) to Measure Ebola's Economic Impacts on Hunger. World Food Programme and Food Security Analysis and Trends Service. Retrieved from https://documents.wfp.org/stellent/groups/public/documents/ena/wfp275534.pdf.

Williams, B., A. Onsman and T. Brown. 2010. "Exploratory Factor Analysis: A Five-step Guide for Novices." Australasian Journal of Paramedicine 8 (3): 1-13.

World Bank. 2014. Update on the Economic Impact of the 2014 Ebola Epidemic on Liberia, Sierra Leone, and Guinea. World Bank Group. Retrieved from www.worldbank.org/ content/dam/Worldbank/document/Economic $\% 20$ Impact $\% 20$ Ebola $\% 20$ Update $\% 20$ 2\%20Dec\%202014.pdf.

Zerai, B. and Z. Gebreegziabher. 2011. "Effect of Nonfarm Income on Household Food Security in Eastern Tigrai, Ethiopia: An Entitlement Approach." Food Science and Quality Management 1: 1-22. 
supplier of raw produce (especially that which is are more than the surplus and reverse threshold) to licensed buying factories ${ }^{5}$ for processing into a variety of nutritionally balanced food.

\section{Recommendations for the Ebola pandemic-affected countries}

There are various ways adoption of the Ghana model could help transform the food and nutrition situation in Sierra Leone, Guinea and Liberia. These could include investment in the following areas.

1 Moving from an endless process of planning to encourage the agriculture and health sectors to actually adopt coherent policies and scale up their investment in agriculture through government-private sector partnerships.

2 Governments and the private sector, especially the banks, should increase investment in rice production, processing and marketing. Here the focus should be on the procurement, management and transportation of modern technology and fertilizer, and selecting, with the help of global positioning systems (GPS), designated arable land where the government and the private sector could cultivate new varieties of crops and livestock.

3 Making youth and women a catalyst for agribusiness development and growth. To achieve this, government should allocate at least $10 \%$ of annual budgets as recommended by the Malabo Declaration on Accelerated Agricultural Growth and Transformation for Shared Prosperity and Improved Livelihood of 2014.

4 Government should also invest in catalytic technology, e.g., mechanization, irrigation and efficient water-management machinery.

5 The government should invest in livestock development and commit to increasing the annual yield of livestock with high source of protein, e.g., guinea fowl, ducks, grasscutters, rabbits and fish. These livestock are already readily available in the Mano River basin region (Sierra Leone, Guinea and Liberia). What is needed is the establishment of buffer stock companies to reach out to small-scale farming communities that have such livestock. That way, communities that lack these livestock can access them through the central agents, the buffer companies.

6 Strengthen sustainable biodiversity conservation and management including forest and tree crop development.

7 Increase production of other crops to ensure diversification.

8 Establish a multi-country consortium to develop a regional nutrition and food program.

\section{Notes}

1 For more on these initiatives see the website of NEPAD. www.nepad.org/content/ about-nepad (accessed: July 23, 2018). 


\section{Food (in) security}

2 However, for this exchange to operate effectively, it has been suggested by experts that the country would need "about 10,000 metric tonne capacity warehouses in strategic locations across the country"; and for participating farmers, they will receive the funds for their commodities a day after the exchange in line with what the GCX model, the “ ' $\mathrm{T}+1$ ' clearing and settlement system” (Ashiadey 2016, paras. 8, 16).

3 According to the MOFA,

To promote agricultural mechanization, 220 tractors and accessories comprising 141 Maize shellers, 77 Multicrop threshers were distributed to farmers and service providers. In 2018, the Ministry will distribute 200 tractors and matching implements; 1,000 power tillers and walking tractors; 30 tractor mounted rippers; 10 tractor drawn rear blade; 10 tractor mounted slasher; 60 boom and orchard sprayers; 4,000 motorized sprayers; 60 mechanical and pneumatic planters; 50 cereal harvesters; 200 multi-crop threshers; 400 irrigation kits (engine and solar powered sprinklers sets); and 100 green house technology for horticulture production.

(Ministry of Food and Agriculture 2018a, 5)

4 The 'One Village One Dam' initiative is aimed at "facilitating the provision of community-owned and managed small-scale irrigation facilities across the country, especially in northern Ghana." Towards this end, the MOFA has, between 2017 and 2018, identified 192 small dams and dugouts in 64 districts for development (Ministry of Food and Agriculture 2018a, 6).

5 As of June 2018, NAFCO has 73 Licensed Buying factions. According to the MOFA, these licensed buying factories also have the mandate to reach out to farmers at their farm gates. They can also buy

cereals from the farmers on behalf of NAFCO. Most of the farms in Ghana are located in remote areas and it would be difficult for NAFCO to reach them all, which is the reason why NAFCO has employed the services of these LBCs to work on their behalf. A margin is added to the farm gate prices for the LBCs prices. The committee takes into consideration factors like transportation, sacks, drying, bagging, sewing and handling to come up with this margin. The LBC prices are as follows; Maize $(100 \mathrm{~kg})$ - Gh $ф 70$ Paddy Rice $(85 \mathrm{~kg})$ - Ghф45 and Soya $(10 \mathrm{~kg})$ - Ghф85.

\section{References}

Abrahams, Zulfa, Zandile Mchiza, and Nelia P. Steyn. 2011. "Diet and Mortality Rates in Sub-Saharan Africa: Stages in the Nutrition Transition." BMC Public Health 11 (1): 801. African Union, The. 2014. Malabo Declaration on Accelerated Agricultural Growth and Transformation for Shared Prosperity and Improved Livelihoods (Malabo, Equatorial Guinea, June 26-27). The African Union Secretariat. https:/au.int/sites/default/files/ documents/31006-doc-malabo_declaration_2014_11_26-.pdf.

Aryeetey, Ernest, and Baah-Boateng. 2007. Growth, Investment and Employment in Ghana. Policy Integration Department, International Labour Office, Geneva. www.oit. org/wcmsp5/groups/public/-dgreports/-integration/documents/publication/ wcms_085043.pdf.

Aryeetey, Ernest, and Augustin Fosu. 2002. Explaining African Economic Growth Performance: The Case of Ghana. Growth Working Paper No. 7. African Economic Research Consortium Research Project on "Explaining African Economic Growth 
Performance. Nairobi, Kenya: African Economic Research Consortium. www.africa portal.org/publications/explaining-african-economic-growth-performance-the-case-ofghana/.

Aryeetey, Ernest, Jane Harrigan, and Machiko Nissanke, eds. 2000. Economic Reforms in Ghana: The Miracle and Mirage. Oxford, UK: James Currey Publishers.

Ashiadey, Bernard Yaw. 2016. "Ghana's Commodities Exchange to Begin Trading 2017." Tralac Trade Law Centre, 2016. www.tralac.org/news/article/9936-ghana-scommodities-exchange-to-begin-trading-2017.html.

Baro, Mamadou, and Tara F. Deubel. 2006. "Persistent Hunger: Perspectives on Vulnerability, Famine, and Food Security in Sub-Saharan Africa." Annual Review of Anthropology 35: 521-538.

Bellamy, Alex J. 2010. Global Politics and the Responsibility to Protect: From Words to Deeds. Routledge.

Berkmen, S. Pelin, Gaston Gelos, Robert Rennhack, and James P. Walsh. 2012. "The Global Financial Crisis: Explaining Cross-Country Differences in the Output Impact." Journal of International Money and Finance 31 (1): 42-59.

Deuss, Annelies. 2014. Review of Stockholding Policies [Paper Prepared for the OECD Global Forum on Agriculture: Issues in Agricultural Trade Policy]. Paris: Trade and Agriculture Directorate, OECD.

Downe-Wamboldt, Barbara. 1992. "Content Analysis: Method, Applications, and Issues." Health Care for Women International 13 (3): 313-321.

Economist Intelligence Unit, The. 2017. Global Food Security Index, 2017: Measuring Food Security and the Impact of Resource Risks. New York, NY: The Economist Intelligence Unit'. https://foodsecurityindex.eiu.com/Home/DownloadResource?fileName= EIU\%20Global\%20Food\%20Security\%20Index\%20-\%202017\%20Findings\%20\% 26\%20Methodology.pdf.

Fjelde, Hanne, and Nina von Uexkull. 2012. "Climate Triggers: Rainfall Anomalies, Vulnerability and Communal Conflict in Sub-Saharan Africa." Political Geography 31 (7): 444-453.

Government of Sierra Leone, and World Food Programme. 2012. The State of Food Security and Nutrition in Sierra Leone, 2011.

Hendrix, Cullen S. and Sarah M. Glaser. 2007. "Trends and Triggers: Climate, Climate Change and Civil Conflict in Sub-Saharan Africa." Political Geography 26 (6): 695-715.

Jayne, T. S. 2012. "Managing Food Price Instability in East and Southern Africa." Global Food Security 1 (2): 143-149.

Jolliffe, Lee. 1993. "Yes! More Content Analyses!” Newspaper Research Journal 14 (3-4): 93-98.

Matthews, Alan. 2003. Regional Integration and Food Security in Developing Countries (Prepared for the Agricultural Policy Support Service, Policy Assistance Division). Vol. 45. Rome: Food and Agriculture Organization of the United Nations.

McTavish, Donald G. and Ellen B. Pirro. 1990. "Contextual Content Analysis." Quality and Quantity 24 (3): 245-265.

Messer, Ellen, and Marc J. Cohen. 2007. "Conflict, Food Insecurity and Globalization." Food, Culture \& Society 10 (2): 297-315.

Ministry of Agriculture. 2008. National Food Security and Nutrition Strategy: A Crosssectoral Strategy for the Government of Liberia. Ministry of Agriculture, Monrovia, Republic of Liberia. Retrieved from www.foodsecurityportal.org/sites/default/files/ National\%20Food\%20Security\%20and\%20Nutrition\%20Strategy_Mar08_0.pdf 


\section{Food (in)security}

Ministry of Food and Agriculture, Government of Ghana. 2017. Planting for Food and Jobs: Strategic Plan for Implementation (2017-2020). Accra: Ministry of Food and Agriculture, Government of Ghana. http://mofa.gov.gh/site/wp-content/uploads/2018/03/ PFJ\%20document\%20New\%20New.pdf.

Ministry of Food and Agriculture, Government of Ghana. 2018a. Medium-Term Expenditure Framework (MTEF) for 2018-2021: Programme Based Budget Estimate. Accra: Ministry of Food and Agriculture. www.mofep.gov.gh/sites/default/files/pbb-estimates/ 2018/2018-PBB-MoI.pdf.

Ministry of Food and Agriculture, Government of Ghana. 2018b. National Food Buffer Stock Company (NAFCO): Background, Mandate, Objectives, and Price Determination. 2018. http://mofa.gov.gh/site/?page_id=705.

Ministry of Food and Agriculture, Government of Ghana. 2018c. Planting for Food and Jobs (PFJ): Frequently Asked Questions (FAQs). 2018. http://mofa.gov.gh/site/?page id $=15114$.

Ofori-Sarpong, E. 1986. “The 1981-1983 Drought in Ghana.” Singapore Journal of Tropical Geography 7 (2): 108-127.

Rimmer, Douglas. 1966. "The Crisis in the Ghana Economy." The Journal of Modern African Studies 4 (1): 17-32.

Shaw, Daniel John. 1991. "Food Aid for Africa in the 1990s." Food Policy 16 (6): 431-435.

Thomas, A.-C., B. D'Hombres, C. Casubolo, F. Kayitakire, and M. Saisana. 2017. The Use of the Global Food Security Index to Inform the Situation in Food Insecure Countries. EUR 28885 EN. Luxembourg: Publications Office of the European Union. http://publi cations.jrc.ec.europa.eu/repository/bitstream/JRC108638/jrc108638-revised_version.pdf.

Trading Economics. 2018. "Ghana Gross Domestic Product: 1960-2018.” 2018. https:// tradingeconomics.com/ghana/gdp.

USAID, M. M. Pasqualino, S. H. Thilsted, M. J. Phillips, and A. S. Koroma. 2016. Food and Nutrition Security in Sierra Leone with a Focus on Fish in Tonkolili District. Washington, DC: http://pubs.iclarm.net/resource_centre/2016-23.pdf.

Walker, Brian, Scott Barrett, Stephen Polasky, Victor Galaz, Carl Folke, Gustav Engström, Frank Ackerman, Ken Arrow, Stephen Carpenter, and Kanchan Chopra. 2009. "Looming Global-Scale Failures and Missing Institutions.” Science 325 (5946): 1345-1346.

Waterbury, John. 1999. "The Long Gestation and Brief Triumph of Import-Substituting Industrialization.” World Development 27 (2): 323-341.

Watkins, Kevin. 1991. "Agriculture and Food Security in the GATT Uruguay Round." Review of African Political Economy 18 (50): 38-50.

World Bank, The, The Natural Resource Institute, and Food and Agricultural Organisation (FAO). 2011. Missing Food: The Case of Postharvest Grain Losses in SubSaharan Africa. Report Number 60371-AFR. Economic and Sector Work. Washington, DC: The World Bank. https://siteresources.worldbank.org/INTARD/ Resources/MissingFoods10_web.pdf. 
households take the necessary steps to embrace income diversification so as to remain resilient to food insecurity during an Ebola pandemic. Future research can use panel data from different Ebola-affected countries to produce more robust estimates.

\section{References}

Blake, Cecil. 2010. The African Origins of Rhetoric. London: Routledge.

Ferreira, Ines Afonso Roque. 2015. "Defining and Measuring State Fragility: A New Proposal.” In, 39. Berkeley, CA. http://cega.berkeley.edu/assets/miscellaneous_files/109_ABCA_2015_Ines_Ferreira_Defining_and_measuring_state_fragility_A_new_pro posal_May15.pdf.

G7+. 2013. "Note on the Fragility Spectrum." G7+. www.g7plus.org/sites/default/files/ resources/g7\%2B\%2BEnglish\%2BFS\%2BNote\%2BDesign.pdf.

Koomson, Isaac, and Simplice A. Asongu. 2016. "Relative Contribution of Child Labour to Household Farm and Non-Farm Income in Ghana: Simulation with Child's Education." African Development Review 28 (1): 104-115.

Lahai, John Idriss, and Tanya Lyons. 2016. African Frontiers: Insurgency, Governance and Peacebuilding in Postcolonial States. London: Routledge.

Ministry of Food and Agriculture, Government of Ghana. 2018. "National Food Buffer Stock Company (NAFCO): Background, Mandate, Objectives, and Price Determination." 2018. http://mofa.gov.gh/site/?page_id=705.

USDOL. 2017. "2016 Findings on the Worst Forms of Child Labour." Bureau of International Labour Affairs, U.S. Department of Labour, https://businessandhumanrights. uconn.edu/wp-content/uploads/sites/1850/2017/11/US-Dept-of-Labor-2016-WorstForms-of-Child-Labor.pdf. 